\title{
Geochemical evaluation of carbonate aquifers in Ngbo and environs, Ebonyi State, southeastern, Nigeria
}

\author{
Ikenna Stanley Ifediegwu ${ }^{1} \cdot$ Chinenye Florence Onyeabor ${ }^{2} \cdot$ Chiamaka Miracle Nnamani $^{2}$
}

Received: 8 May 2019 / Accepted: 10 September 2019 / Published online: 26 September 2019

(C) The Author(s) 2019

\begin{abstract}
The geochemical evaluation of carbonate aquifers in Ngbo and environs has been executed to ascertain the major ion chemistry and quality of waters for domestic and drinking uses. Ten water samples were gathered from pit lakes, hand dug wells, boreholes and rivers. The collected samples were analysed for $\mathrm{pH}, \mathrm{EC}$, TDS, $\mathrm{Ca}^{2+}, \mathrm{Mg}^{2+}, \mathrm{Na}^{+}, \mathrm{K}^{+}, \mathrm{HCO}_{3}{ }^{-}, \mathrm{Cl}^{-}, \mathrm{SO}_{4}{ }^{2-}$, $\mathrm{NO}_{3}{ }^{-}$and $\mathrm{PO}_{4}{ }^{2-}$ in the laboratory using the standard methods. The results were compared with NDWQS and WHO standards. The physical parameters varied from $\mathrm{pH}(6.2-8.4)$, temp. $\left(25.0-26.0^{\circ} \mathrm{C}\right)$, electrical conductivity $(4.9-102 \mu \mathrm{S} / \mathrm{cm})$ and total dissolved solids $(25.5-214.2 \mathrm{mg} / \mathrm{l})$. The analysed results revealed the mean concentration of cations and anions in the following order: $\mathrm{Ca}^{2+}>\mathrm{Mg}^{2+}>\mathrm{Na}^{+}>\mathrm{K}^{+}>\mathrm{Fe}^{2+}$ and $\mathrm{HCO}_{3}{ }^{-}>\mathrm{CO}_{3}{ }^{2-}>\mathrm{SO}_{4}{ }^{2-}>\mathrm{Cl}^{-}$, respectively. Based on the standard limits, about $90 \%$ of the waters in the study area is suitable for domestic and drinking purposes. The Piper trilinear, Stiff and Durov diagrams showed that water samples from various locations fall into mixed $\mathrm{CaCO}_{3}{ }^{2-}+\mathrm{HCO}_{3}$ type. Various ionic ratio plots show that water sources are from dissolution of minerals in the aquifer media. Geochemical parameters such as $\mathrm{Cl}^{-}, \mathrm{Na}^{+}$and $\mathrm{K}^{+}$show good interrelationship with positive factor loadings among the ions.
\end{abstract}

Keywords Geochemical processes $\cdot$ Carbonate aquifer $\cdot$ Hydrochemical facies $\cdot$ Correlation matrix

\section{Introduction}

Water is considered as fresh water exclusively if it generally contains $\mathrm{Ca}^{2+}$ as primary cation and $\mathrm{HCO}_{3}{ }^{-}$as principal anion. The $\mathrm{H}_{2} \mathrm{CO}_{3}, \mathrm{HCO}_{3}{ }^{-}, \mathrm{CO}_{3}{ }^{2-}, \mathrm{OH}^{-}$and $\mathrm{H}^{+}$are the major carbonic species found in water body (Panthi 2003). Most of the groundwater resources rich in $\mathrm{Ca}^{2+}$ ion concentrations are considered safe for drinking (Castanier et al. 1999). The deposition of limestone within an environment has been proven to be the natural source of $\mathrm{CaCO}_{3}$ in water resources (Kile et al. 2000). However, the physico-chemical

Ikenna Stanley Ifediegwu

ifestanley11@gmail.com

Chinenye Florence Onyeabor

edeaninenye@esut.edu.ng

Chiamaka Miracle Nnamani

miraclechiamaka96@gmail.com

1 Department of Geology, Faculty of Physical Sciences, University of Nigeria, Nsukka, Enugu, Nigeria

2 Department of Geology and Mining, Faculty of Physical Natural Sciences, Enugu State University of Science and Technology, Enugu, Enugu, Nigeria component of groundwater in carbonate aquifers is governed by composition of water replenishment, chemical and mineralogic constitutions of the aquifer bed rocks, the residence time, hydrogeologic characteristics of the underlying rocks which govern water-rock interactions and groundwater flow, such as hydraulic conductivity and the flow regime (Moral et al. 2008).

In recent times, the chemistry of groundwater in carbonate aquifers has received considerable attention from researchers all over the world due to its heterogeneity and susceptibility to chemical pollution from human activities (Field 1988; White et al. 1995; Romanov et al. 2003). Owing to the modification in development of groundwater in carbonate aquifer, Hughes et al. (1994) stated that geological structures and hydrogeological systems within carbonate aquifers are extremely complex. On the other hand, Plummer et al. (1990) opined that dedolomitization influenced by gypsum dissolution is a major factor controlling the origin of water chemistry in the carbonate aquifers. Hanshaw and Back (1979) stipulated the geochemical changes in carbonate aquifer systems and their hydrogeological deductions. Jalali (2005) reported that the dissolution of carbonate minerals, cation exchange and weathering 
of silicates influences the chemical composition of groundwater in semiarid region of western Iran. Igwe et al. (2018) in their work on quality of natural waters in carbonate aquifers at a densely populated Odukpani area of Cross River State, Southern Nigeria stated that precipitation and dissolution of carbonate minerals within the aquifers are likely contributing to the modification of flow characteristics of the aquifer matrices.

In the study area, the understanding of various geochemical processes controlling carbonate aquifer has not been given considerable attention it required; hence, the aim of this study is to establish the hydro-geochemical process influencing modifications in the water quality.

\section{Study area}

\section{Location}

Ngbo is located in the north-western part of Ebonyi State, Southeastern, Nigeria. The area, comprising approximately $181 \mathrm{~km}^{2}$, is bounded within latitudes $6^{\circ} 25^{\prime} 0^{\prime \prime} \mathrm{N}$ to $6^{\circ} 31^{\prime} 0^{\prime \prime}$
$\mathrm{N}$ and longitudes $7^{\circ} 58^{\prime} 0^{\prime \prime} \mathrm{E}$ to $8^{\circ} 3^{\prime} 0^{\prime \prime} \mathrm{E}$, with estimated population density of about 234,532 people. The study area bordered with Benue State in the north, Ezza North to the South, Ishielu in the west and Ebonyi Local Government Area to the east. Figure 1 shows the geographical map of Ebonyi State showing the study area.

\section{Topography, drainage, climate and vegetation of the study area}

The area is characterized by vast low-lying plain with elevation varying from 50 to $100 \mathrm{~m}$ above sea level (Umeji 2000). Ngbo is drained by Ebonyi River and its associated streams, which include Ngene Ava, Nsu, Amanata and Ogurube stream. These streams are ephemeral and dry up soon after rainy season. Consequently, during the rainy season, these streams overflow its banks and cause flooding and water logged. As described by Igbozuluike (1975), the study area falls within the humid rainforest region of southeastern Nigeria with annual rainfall between 1750 and $2500 \mathrm{~mm}$ per annum. The area is also characterized by a tropical climate with rainy and seasons. The rainy season spans from April

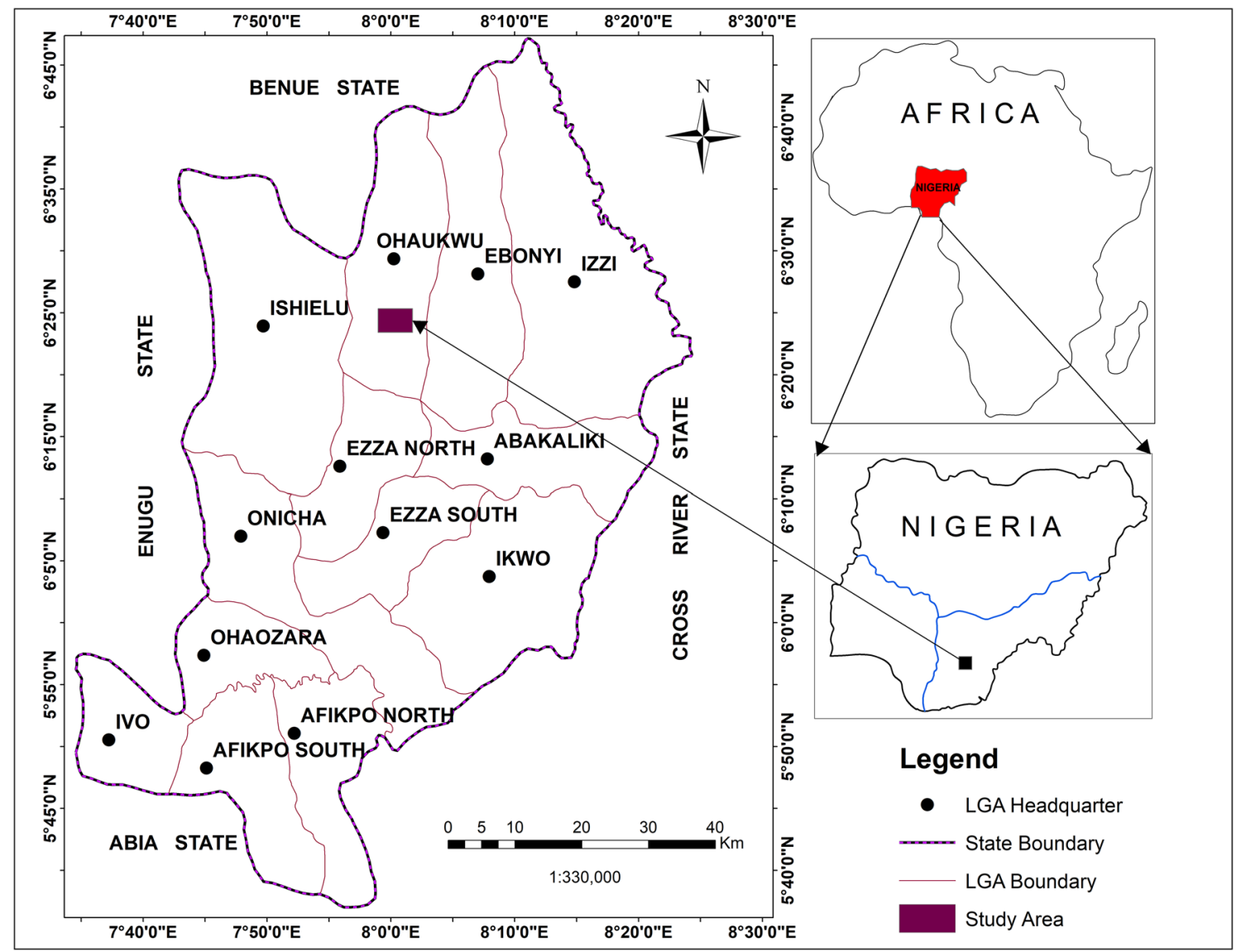

Fig. 1 Geographical map of Ebonyi State showing the study area 
to October, whereas the dry season lasts from November to March. The average temperature in the area ranges from $29^{\circ}$ to $30^{\circ} \mathrm{C}$.

\section{Geologic and hydrogeology}

The geology and hydrogeology of the study area have been studied by various researchers at different scopes (Reyment

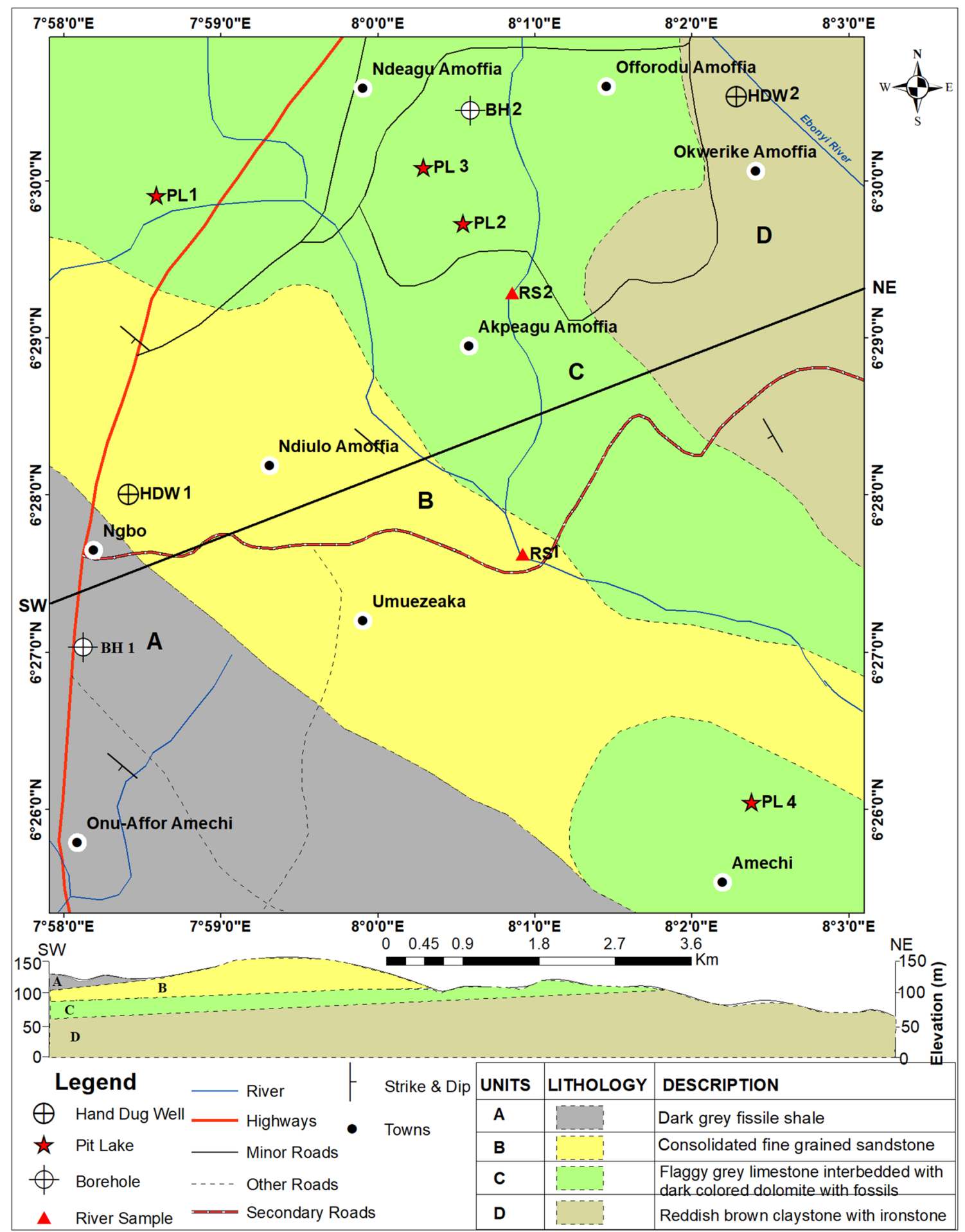

Fig. 2 Geologic map of the study area 


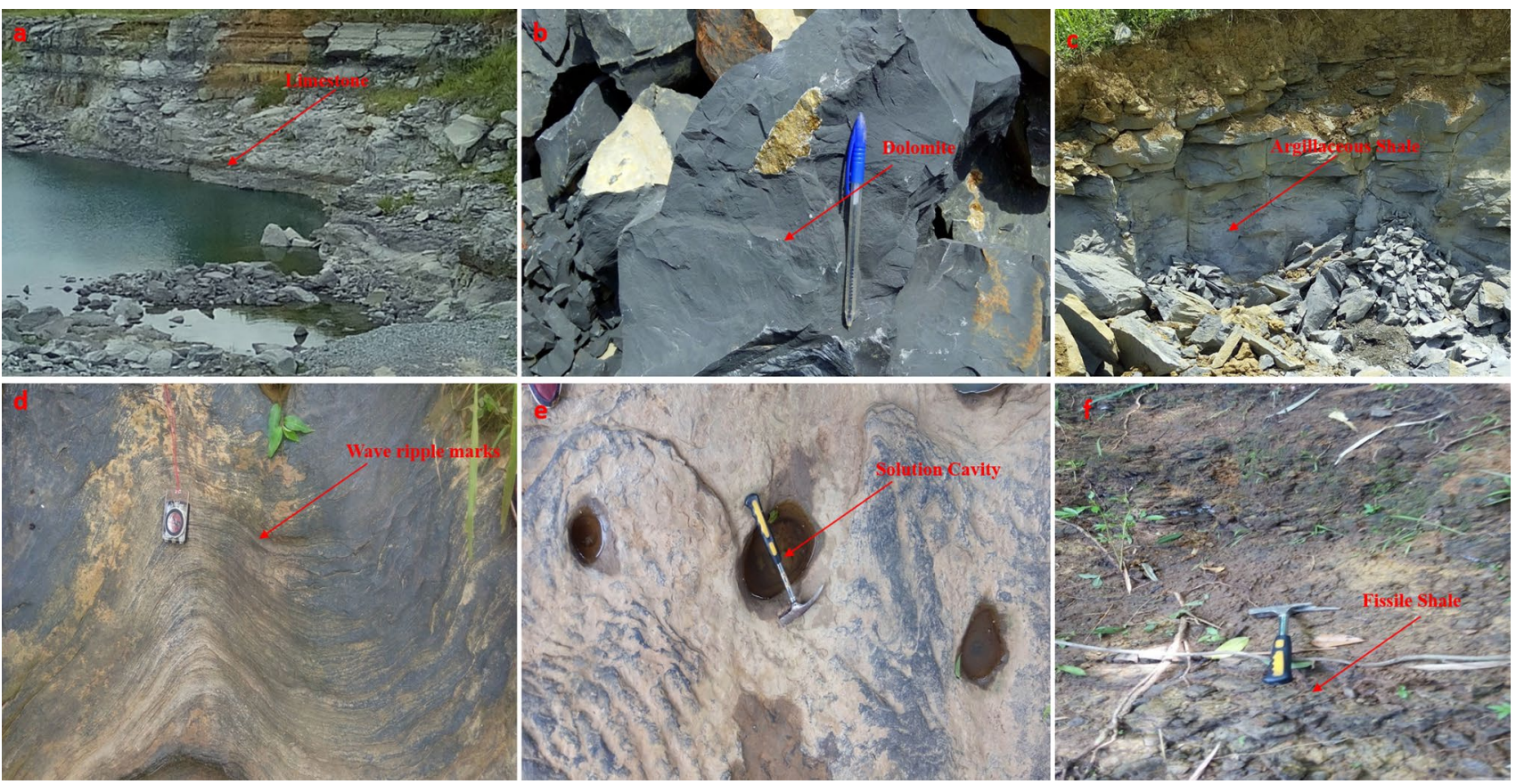

Fig. 3 Pictures of rock units visited in the study area
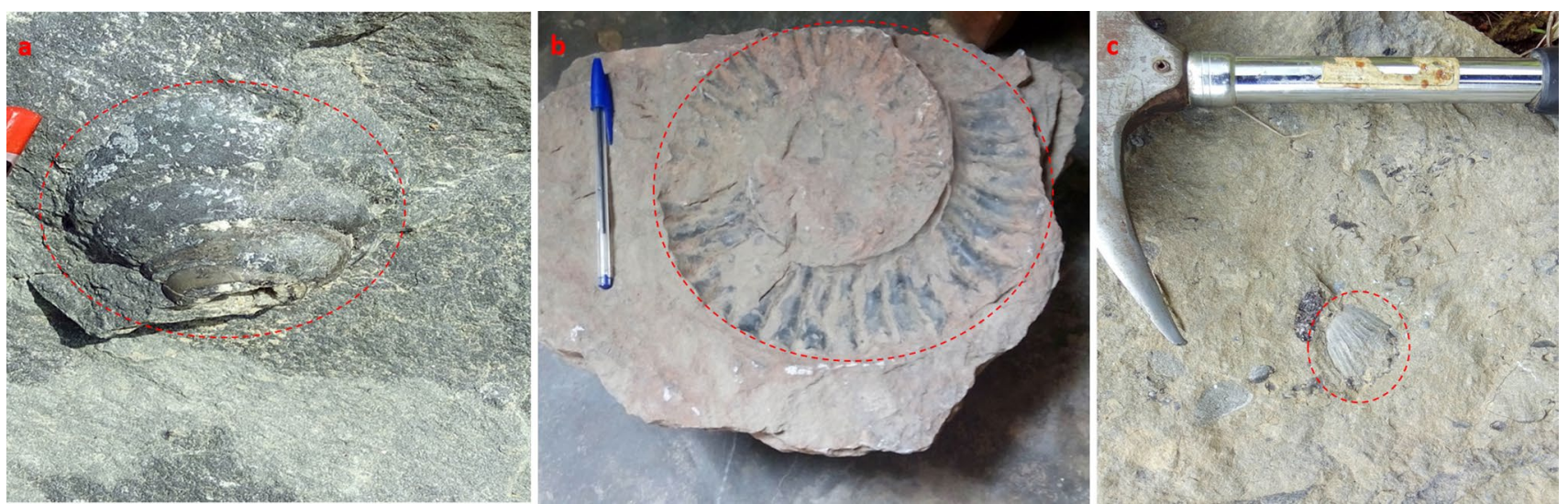

Fig. 4 Picture of fossils imprints encountered in the study area during the field work

Table 1 Summary of sample collection

\begin{tabular}{lllll}
\hline S/N & Location & Sample ID & \multicolumn{2}{l}{ Georeferencing } \\
\cline { 4 - 5 } & & Latitude & Longitude \\
\hline 1 & Lampet Mining Pit & PL 1 & $6^{\circ} 29^{\prime} 56.33^{\prime \prime} \mathrm{N}$ & $7^{\circ} 58^{\prime} 34.31^{\prime \prime} \mathrm{E}$ \\
2 & Ngbo Borehore & BH 1 & $6^{\circ} 27^{\prime} 4.19^{\prime \prime} \mathrm{N}$ & $7^{\circ} 58^{\prime} 6.11^{\prime \prime} \mathrm{E}$ \\
3 & MBC Daniel Mining Pit & PL 2 & $6^{\circ} 29^{\prime} 44.46^{\prime \prime} \mathrm{N}$ & $8^{\circ} 0^{\prime} 31.54^{\prime \prime} \mathrm{E}$ \\
4 & Enerco Mining Pit & PL 3 & $6^{\circ} 30^{\prime} 7.46^{\prime \prime} \mathrm{N}$ & $8^{\circ} 0^{\prime} 16.70^{\prime \prime} \mathrm{E}$ \\
5 & Stone Pile Mining Pit & PL 4 & $6^{\circ} 26^{\prime} 4.09^{\prime \prime} \mathrm{N}$ & $8^{\circ} 2^{\prime} 22.09^{\prime \prime} \mathrm{E}$ \\
6 & Ogwurube River & RS 1 & $6^{\circ} 27^{\prime} 38.32^{\prime \prime} \mathrm{N}$ & $8^{\circ} 0^{\prime} 55.29^{\prime \prime} \mathrm{E}$ \\
7 & Ngbo Hand Dug Well & HDW 1 & $6^{\circ} 28^{\prime} 2.06^{\prime \prime} \mathrm{N}$ & $7^{\circ} 58^{\prime} 23.17^{\prime \prime} \mathrm{E}$ \\
8 & Ndeagu Amoffia Borehole & BH 2 & $6^{\circ} 30^{\prime} 33.43^{\prime \prime} \mathrm{N}$ & $8^{\circ} 0^{\prime} 35.25^{\prime \prime} \mathrm{E}$ \\
9 & Dev. Center Hand Dug Well & HDW2 & $6^{\circ} 30^{\prime} 33.43^{\prime \prime} \mathrm{N}$ & $8^{\circ} 2^{\prime} 16.16^{\prime \prime} \mathrm{E}$ \\
10 & Ngene Ava River & RS 2 & $6^{\circ} 29^{\prime} 17.00^{\prime \prime} \mathrm{N}$ & $8^{\circ} 0^{\prime} 50.09^{\prime \prime} \mathrm{E}$ \\
\hline
\end{tabular}


Table 2 Results of physico-chemical parameters of the study area

\begin{tabular}{|c|c|c|c|c|c|c|c|c|c|c|c|c|}
\hline Parameters (mg/l) & PL 1 & BH 1 & PL 2 & PL 3 & PL 4 & RS 1 & HDW1 & $\mathrm{BH} 2$ & HDW2 & RS 2 & NDWQS (2007) & WHO (2011) \\
\hline $\mathrm{pH}$ & 7.5 & 6.3 & 8.1 & 7.7 & 8.4 & 6.2 & 7.8 & 6.6 & 8.1 & 6.5 & $6.5-8.5$ & $6.5-8.8$ \\
\hline Temp. $\left({ }^{\circ} \mathrm{C}\right)$ & 25.6 & 25.5 & 26.0 & 25.7 & 25.8 & 26.0 & 25.5 & 25.0 & 25.0 & 25.7 & Ambient & Ambient \\
\hline $\mathrm{EC}(\mu \mathrm{s} / \mathrm{cm})$ & 7.2 & 4.9 & 52 & 58 & 96 & 70 & 75 & 100 & 92 & 102 & 1000 & 1250 \\
\hline TDS & 161.9 & 165.9 & 214.2 & 25.5 & 93.7 & 135.7 & 46.8 & 121.5 & 93.7 & 161.0 & 500 & 500 \\
\hline $\mathrm{Ca}^{2+}$ & 47.9 & 102.6 & 86.4 & 112.6 & 62.8 & 108.5 & 100.1 & 68.3 & 74.9 & 47.6 & 75 & 75 \\
\hline $\mathrm{Mg}^{2+}$ & 28.2 & 19.3 & 40.0 & 35.7 & 40.0 & 17.0 & 54.8 & 42.7 & 28.2 & 10.9 & - & 50 \\
\hline $\mathrm{Na}^{+}$ & 16.08 & 1.62 & 1.02 & 4.81 & 1.43 & 0.96 & 1.05 & 1.62 & 3.81 & 1.02 & - & 200 \\
\hline $\mathrm{K}^{+}$ & 0.98 & 1.56 & 1.23 & 0.27 & 2.07 & 0.98 & 2.11 & 1.12 & 0.37 & 1.41 & - & - \\
\hline $\mathrm{Cl}^{-}$ & 1.53 & 1.02 & 0.81 & 1.02 & 1.02 & 9.6 & 1.86 & 3.03 & 4.51 & 0.81 & 250 & 200 \\
\hline $\mathrm{SO}_{4}{ }^{2-}$ & 4.9 & 2.6 & 2.6 & 6.8 & 3.4 & 2.9 & 2.9 & 4.1 & 6.9 & 2.6 & 100 & 200 \\
\hline $\mathrm{CO}_{3}^{2-}$ & 6.6 & 19.8 & 24.2 & 10.6 & 13.2 & 5.28 & 36.7 & 40.2 & 19.8 & 6.6 & - & - \\
\hline $\mathrm{HCO}_{3}^{-}$ & 30.01 & 20.12 & 60.20 & 80.13 & 20.11 & 10.10 & 20.00 & 20.19 & 18.57 & 25.09 & - & 100 \\
\hline $\mathrm{Fe}^{3+}$ & 0.000 & 0.001 & 0.000 & 0.003 & 0.000 & 0.001 & 0.04 & 0.003 & 0.000 & 0.04 & & 0.3 \\
\hline B $(\mu \mathrm{g} / 1)$ & 0.002 & 0.011 & 0.002 & 0.007 & 0.022 & 0.026 & 0.001 & 0.007 & 0.020 & 0.002 & - & - \\
\hline
\end{tabular}

1965; Murat 1972; Petters and Ekweozor 1982; Agagu et al. 1985; Nwajide 1990; Petters 1991; Ojoh 1992; Nwajide 2013). The major two geological formations underlying the study area is Abakaliki (Albian) and Ezeaku Formations (Turonian). These formations consisting of dark grey coloured fissile shale, reddish brown claystone interbedded with ferrugnized ironstone, and flaggy grey limestone interbedded with dark coloured dolomite with fossil imprints like gastropoda, ammonite, pelecypoda and brachiopoda have been reported by Umeji $(1984,1993)$. These rocks were designated as units A, B, C and D in Fig. 2, whereas Figs. 3 and 4 show the pictures of rock units visited in the area.

Hydrologically, the area is characterized by two aquifer systems: the shallow unconfined and deep confined aquifer systems (Uma et al. 1990). The shallow unconfined aquifers as shown in Fig. 5 appeared within fractured, weathered, jointed shale and some patches of sandstone in the areas of the undertaken studies.

\section{Materials and methods}

\section{Sampling}

Ten surface and groundwater samples were collected from motorized boreholes, hand dug wells, pit lakes and streams with 1 litre polyethylene bottles (Table 1, Fig. 6). The samples bottles were soaked in $10 \% \mathrm{HNO}_{3}$ for 24 hours and rinsed several times with deionized water prior to use. At each sampling locations, the bottles were thoroughly rinsed with the water to be sampled before collection, tightly closed leaving air bubble below the stopper, labelled proper and stored in cooler. The samples were sent to laboratory for chemical analysis within the 24 hours of collection.

\section{Sample analysis}

The in-situ measurements of $\mathrm{pH}$, temperature, $\mathrm{EC}, \mathrm{CaCO}_{3}$ and TDS were carryout in the field using multiple EXTECH (341350A) PH/Conductivity/TDS/Salinity/ORP Meter. Prior to measurement of $\mathrm{pH}$, the electrode was calibrated using pH 6.88 and 4.01 buffer solutions at the same manner EC and TDS of the water samples were measured. Temperature was determined using alcoholic thermometer. The $\mathrm{HCO}_{3}$ and $\mathrm{CO}_{3}{ }^{2-}$ were measured by titration using methyl orange and HCL $0.05 \mathrm{~N}$ as indicator. $\mathrm{SO}_{4}{ }^{2-}$ by turbidmetery using visible light spectrophotometer. Ion such as $\mathrm{Ca}^{2+}, \mathrm{Mg}^{2+}, \mathrm{B}$ and $\mathrm{K}^{+}$were determined in the lab using the Buck Model 210/211 AAS 220GF graphite Furnance and 220 AS Autosampler, which was calibrated by 2-point calibration using the appropriate Matrix Blank for the flame and the standard set within the calmax range for each element. The conditions which the cations were done is by Air/Acetylene Flame, $\mathrm{N}_{2} \mathrm{O}$ /Acetylene Flame, Integrated mode, Normal parameter (Sodium $(\mathrm{Na})$ is done by emission mode) and the samples were digested using Nitric Acid per chloric Acid.

\section{Geochemical interpretations}

The spatial distributions and illustrations of the hydrochemical facies were perfumed using ArcGis 10.4 and Rockworks computer processing software package. However, the statistical analysis of the geochemical data was determined with the aid of Statigraphics software.

\section{Results and discussion}

The results obtained during the undertaken studies is presented in Table 2. It was found that the physico-chemical 


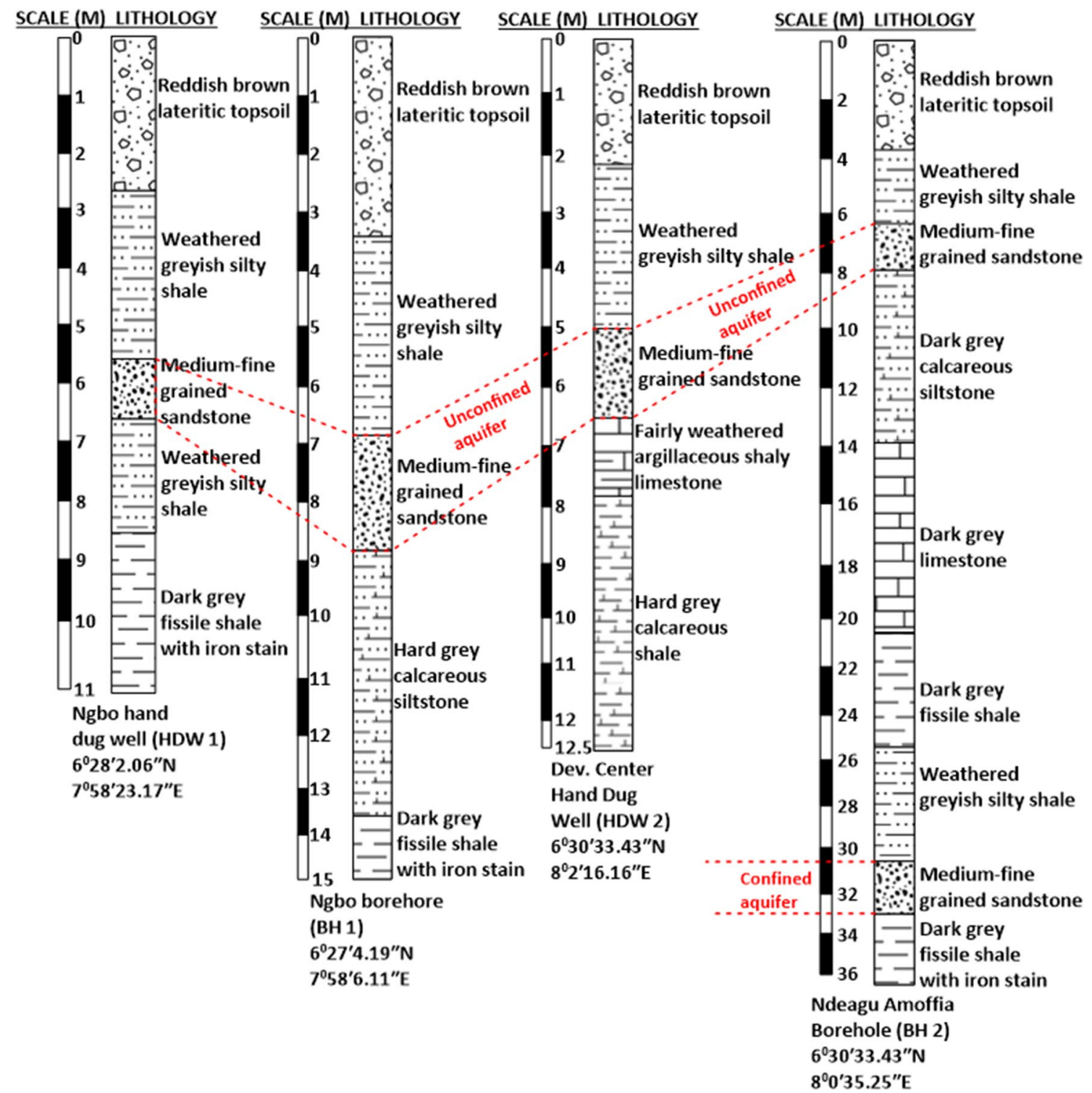

Fig. 5 Revealed the borehole log of the area

composition of the water samples was highly different in every areas of the undertaken studies.

\section{$\mathrm{pH}$ and temperature}

The $\mathrm{pH}$ value of water samples in the study ranged from minimum 6.2 to 8.4 with the least value observed in Ogwurube River (RS 1), while the maximum value was recorded at Stone Pile Mining Pit (PL 4). The $\mathrm{pH}$ of the water samples indicates mildly acidic to alkaline in nature. $\mathrm{pH}$ was within the NDWQS (2007) and WHO (2011) acceptable level. This is consistent with the studies carried out by Ozoko (2015) in the study area. The alkaline $\mathrm{pH}$ values obtained may have been as a result of partial neutralization of the bed rocks by the amount of dissolved $\mathrm{CO}_{2}$, carbonate and bicarbonate in water (Ghandour et al. 1985). The temperature ranged from 25.0 to $26.0^{\circ} \mathrm{C}$ with the least value observed at Ndeagu Amoffia Borehole (BH 2) and Dev. Center Hand Dug Well (HWD 2), while the maximum value was recorded in MBC Daniel Mining Pit (PL 2) and Ogwurube River (RS 1). The temperature values were within the applicable regulation which requires ambient levels.

\section{Electrical conductivity and total dissolved solid}

EC varied from $4.9 \mu \mathrm{s} / \mathrm{cm}$ to $102 \mu \mathrm{s} / \mathrm{cm}$ with average value of $65.71 \mu \mathrm{s} / \mathrm{cm}$. EC had the highest concentration of $102 \mu \mathrm{s} /$ $\mathrm{cm}$ at Ngene Ava River (RS 2), while the minimum value of $4.9 \mu \mathrm{s} / \mathrm{cm}$ was recorded at Ngbo Borehole (BH 1). The elevated value of EC at RS 2 suggests mineral dissolution. 


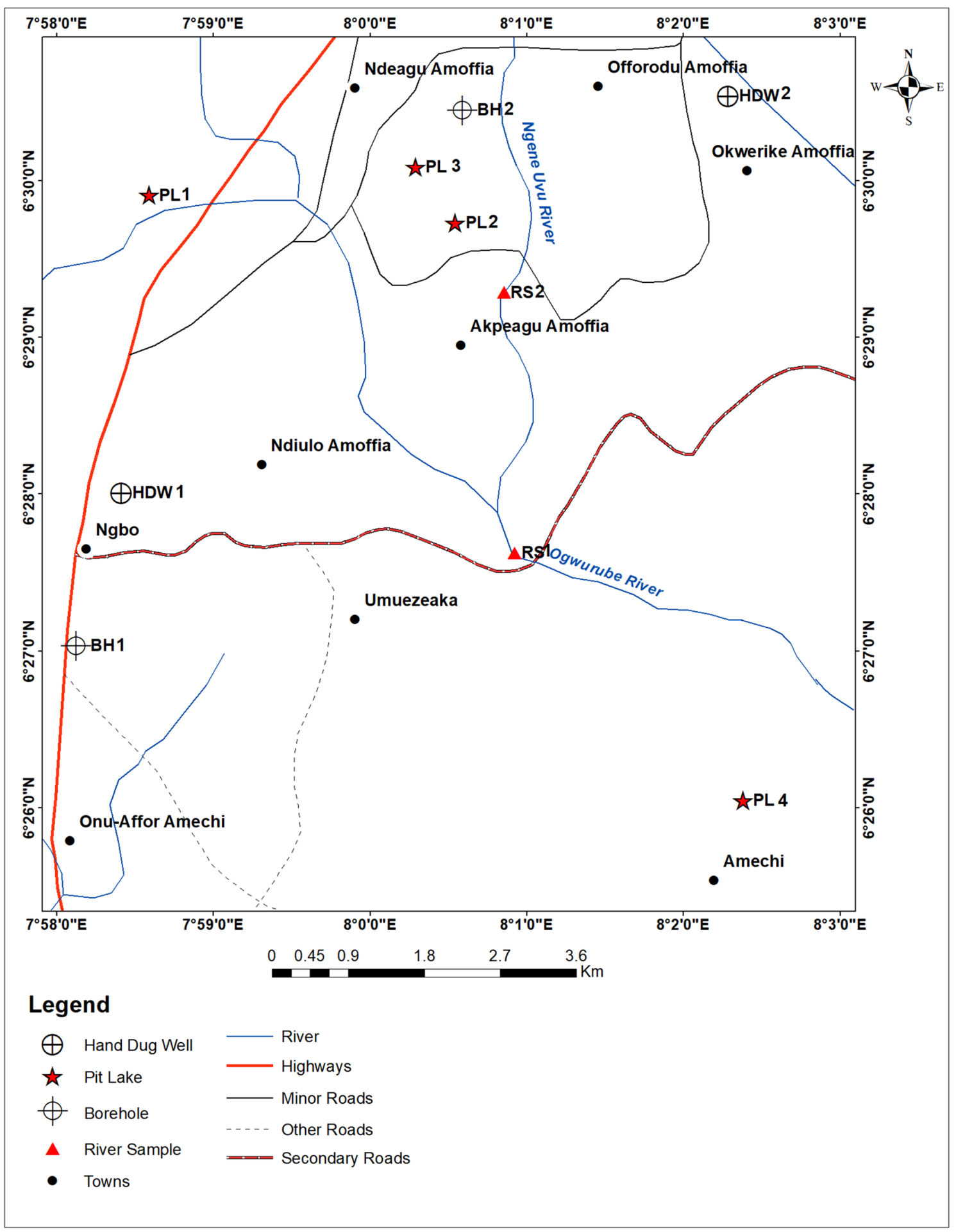

Fig. 6 Sampling map of the study area

The electrical conductivity (EC) for all the water samples fell within the permissible limit of $1000 \mu \mathrm{s} / \mathrm{cm}$ and $1250 \mu \mathrm{s} /$ $\mathrm{cm}$ set by NDWQS (2007) and WHO (2011). Similarly, TDS fluctuate between $25.5 \mathrm{mg} / \mathrm{L}$ at Enerco Mining Pit (PL 3) to
$214 \mathrm{mg} / \mathrm{L}$ at MBC Daniel Mining Pit (PL 2) with average value of $121.99 \mathrm{mg} / \mathrm{L}$. These values are in agreement with research carried out by Igwe et al. (2018). These results indicate fresh to moderately mineralized water. According to the 
Table 3 Classification of water quality based on salinity values (Robinove et al. 1958)

\begin{tabular}{lll}
\hline No. of sample & TDS $(\mathrm{mg} / \mathrm{L})$ & Interpretation \\
\hline 10 & $<1000$ & Non-saline \\
0 & $1000-3000$ & Slightly saline \\
0 & $3000-10,000$ & Moderately saline \\
0 & $>10,000$ & Highly saline \\
Total $=10$ & & \\
\hline
\end{tabular}

standard proposed by NDWQS (2007) and WHO (2011), the values of TDS are $500 \mathrm{mg} / \mathrm{L}$ and $1200 \mathrm{mg} / \mathrm{L}$. TDS values fell below NDWQS and WHO permissible limits. The entire water samples are non-saline (Table 3 ) based on the salinity classification suggested by Robinove et al. (1958).

\section{Calcium and magnesium}

The $\mathrm{Ca}^{2+}$ values are generally above NDWQS (2007) and WHO (2011) permissible limit $75 \mathrm{mg} / \mathrm{L}$, varying from $47.6 \mathrm{mg} / \mathrm{L}$ at Ngene Ava River (RS 2) to $112.6 \mathrm{mg} / \mathrm{L}$ at Enerco Mining Pit (PL 3) with average value of $81.17 \mathrm{mg} / \mathrm{L}$ (Fig. 7). The highest concentration of $\mathrm{Ca}^{2+}$ observed at Enerco Mining Pit (PL 3) is expected to come from main rock types in the area where limestone and dolomite are the most dominant geological units. Consequently, the acceptable limit of $\mathrm{Mg}^{2+}$ is $30 \mathrm{mg} / \mathrm{L}$. The values obtained for magnesium ranged from $10.9 \mathrm{mg} / \mathrm{L}$ at Ngene Ava River (RS 2) to $54.8 \mathrm{mg} / \mathrm{L}$ at $\mathrm{Ngbo}$ hand dug well with average value of $31.68 \mathrm{mg} / \mathrm{L}$ with average value of $31.68 \mathrm{mg} / \mathrm{L}$. Higher concentration of $\mathrm{Mg}^{2+}$ was observed at PL 2, PL 3, PL 4, HDW 1 and $\mathrm{BH} 2$, respectively. The dissolution of calcite and dolomite in the carbonate aquifers in the study area generally accounts for the $\mathrm{Ca}^{2+}$ and $\mathrm{Mg}^{2+}$ concentration in the surface water and groundwater.

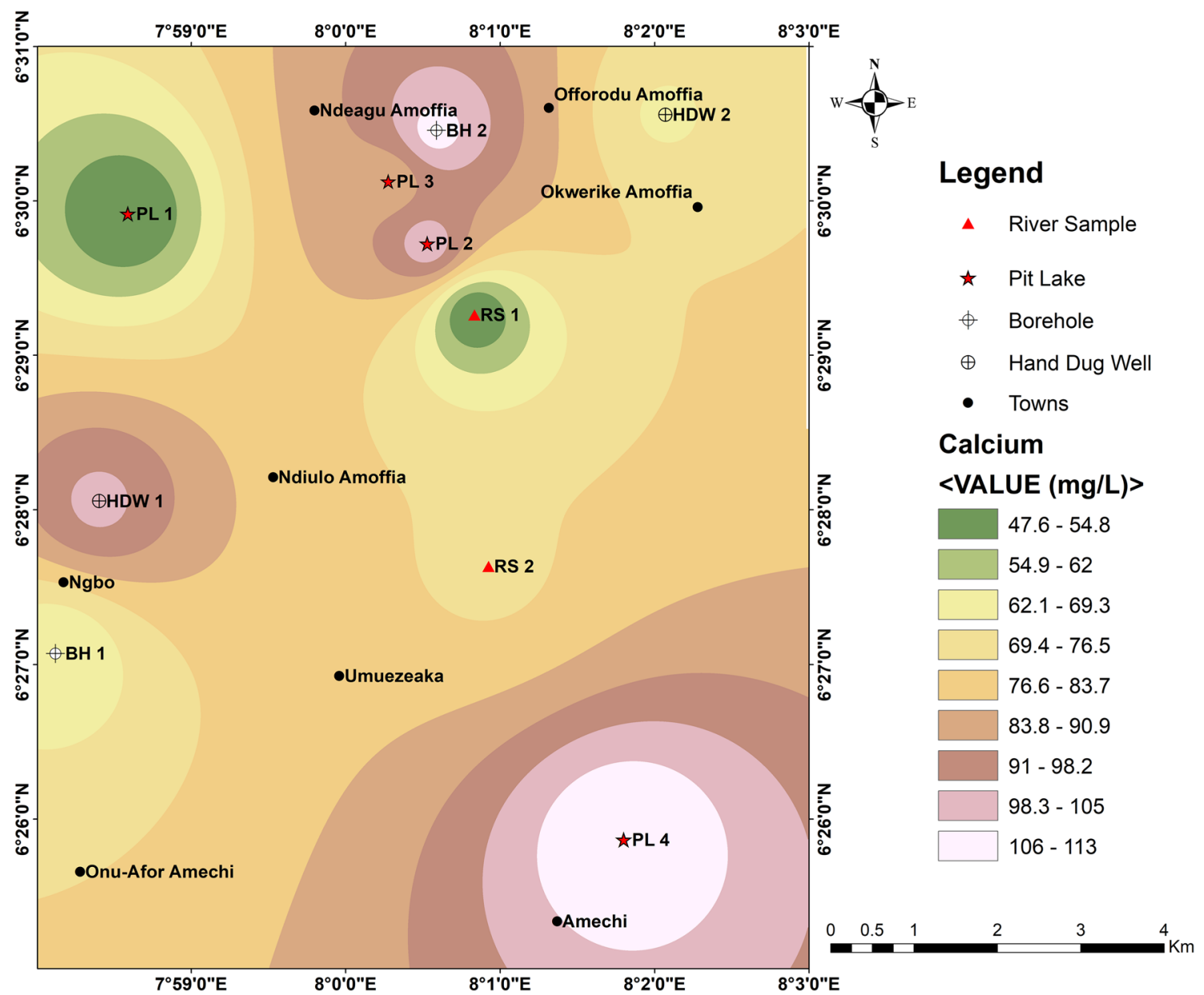

Fig. 7 Spatial distributions of calcium in the study area 


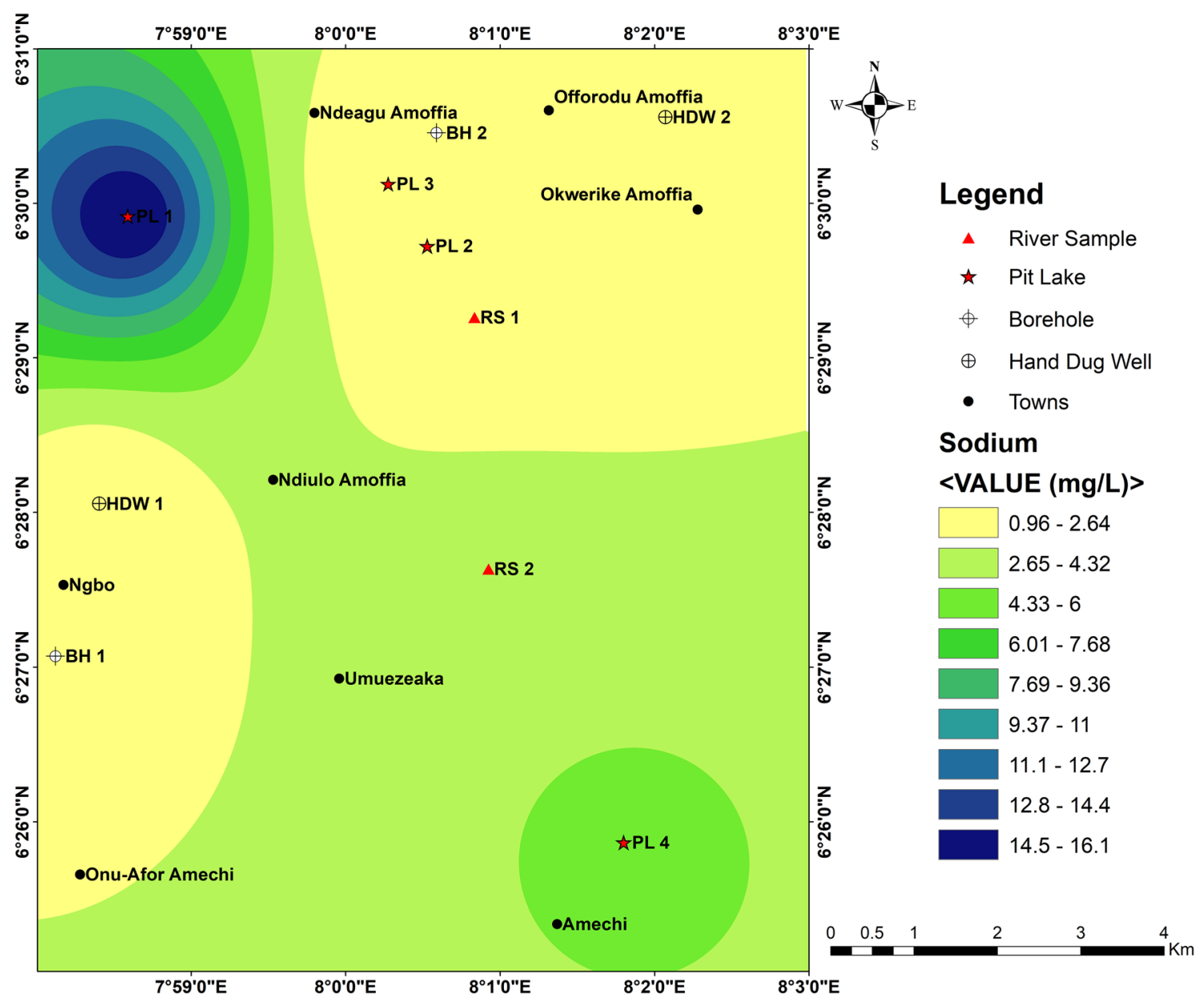

Fig. 8 Spatial distributions of sodium in the study area

\section{Sodium and potassium}

The estimated $\mathrm{Na}$ content from collected water samples ranged from $1.02 \mathrm{mg} / \mathrm{L}$ at MBC Daniel Mining Pit (PL 2) and Ngene Ava River (RS 2) to $16.08 \mathrm{mg} / \mathrm{L}$ at Lampet Mining Pit (PL 1) with average value of $3.34 \mathrm{mg} / \mathrm{L}$ (Fig. 8). Most of the samples have sodium levels that are not in excess of the permissible limit of $200 \mathrm{mg} / \mathrm{L}$ stipulated by WHO (2011). However, the potassium of analysed water samples varied from $0.27 \mathrm{mg} / \mathrm{L}$ to $2.11 \mathrm{mg} / \mathrm{L}$. The highest value of potassium was observed at Ngbo Hand Dug Well (HDW 1) with average of value of $1.21 \mathrm{mg} / \mathrm{L}$. No health base guideline values have been derived (NDWQS 2007; WHO 2011) for potassium. The presence of sodium and potassium in the water samples may emanate from ancient sea intrusion.

\section{Chloride and sulphate}

The maximum permissible limit of chloride in potable water is $200 \mathrm{mg} / \mathrm{l}$. In the study area, the analysed water samples, the concentration of chloride fluctuate between $0.81 \mathrm{mg} / \mathrm{L}$ at MBC Daniel Mining Pit (PL 2) and Ngene Ava River (RS 2) to $9.6 \mathrm{mg} / \mathrm{L}$ at Ogwurube River (RS 1) with average value of $2.52 \mathrm{mg} / \mathrm{L}$ (Fig. 9). They are generally low. The chloride content of the water sample when compared with NDWQS and WHO standard showed that all samples had concentration within the permissible limit. Moreover, the acceptable limit of sulphate as stipulated by NDWQS (2007) is $100 \mathrm{mg} / \mathrm{L}$ and WHO (2011) is $200 \mathrm{mg} / \mathrm{L}$. The sulphate content in the water samples varied from $2.6 \mathrm{mg} / \mathrm{L}$ at Ngbo Borehole (BH 1), MBC Daniel Mining Pit (PL 2) and Ngene Ava River (RS 2) to $6.9 \mathrm{mg} / \mathrm{L}$ at Dev. Center Hand Dug Well (HDW 2) as shown in Table 2. The entire samples found to be well within permissible limit.

\section{Carbonate and bicarbonate}

The availability of $\mathrm{CO}_{3}{ }^{2-}$ and $\mathrm{HCO}_{3}{ }^{-}$in water is associated with calcium- and magnesium-rich minerals. In the study 


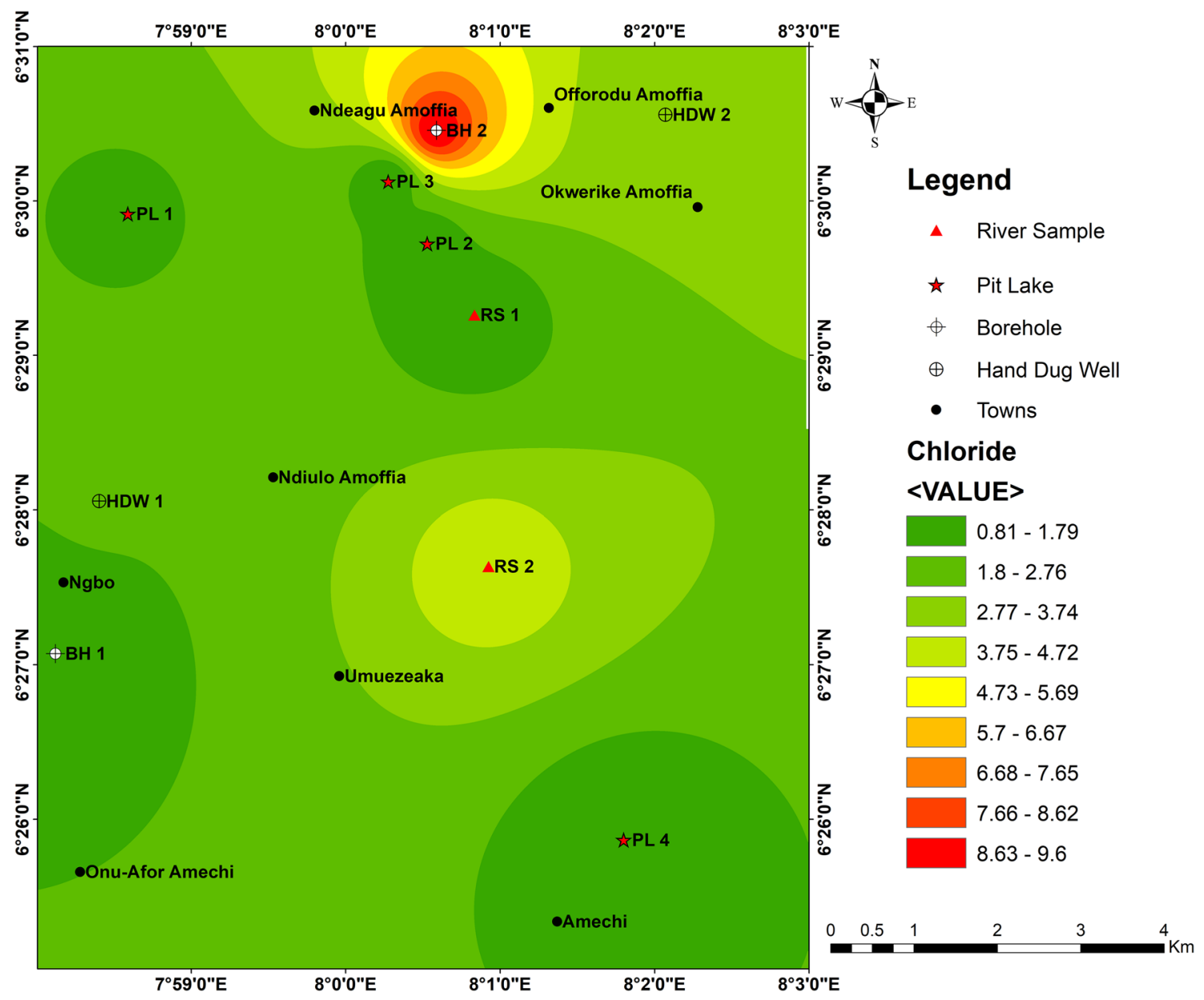

Fig. 9 Spatial distributions of chloride in the study area

area, the concentration of $\mathrm{CO}_{3}{ }^{2-}$ in the water samples varied from 5.28 at Ogwurube River (RS 1) to $40.2 \mathrm{mg} / \mathrm{L}$ at Ndeagu Amoffia Borehole (BH 2) with average value of $18.29 \mathrm{mg} / \mathrm{L}$ (Fig. 10). Similarly, the analysed $\mathrm{HCO}_{3}{ }^{-}$concentration from the collected water samples ranged from $10.10 \mathrm{mg} / \mathrm{L}$ at Ogwurube River (RS 1) to $60.20 \mathrm{mg} / \mathrm{L}$ at MBC Daniel Mining Pit (PL 2) with average value of $30.45 \mathrm{mg} / \mathrm{L}$. According to WHO (2011), the maximum acceptable concentration of $\mathrm{HCO}_{3}{ }^{-}$in water for domestic purposes is $100 \mathrm{mg} / \mathrm{L}$. All the water samples have $\mathrm{HCO}_{3}{ }^{-}$values well within the permissible limit of WHO (2011). These results obtained are mainly attributed to the weathering-dissolution of carbonate minerals in the study area.

\section{Iron and boron}

The levels of iron in the water samples are generally within the acceptable limits of WHO and NDWQS but some were unacceptable under the standard guidelines (Table 2). Iron content ranges from $0.000 \mathrm{mg} / \mathrm{L}$ (PL 1, BH 1, PL 2, PL 3,
PL 4, HDW1, BH 2 and HDW2) to $0.04 \mathrm{mg} / \mathrm{L}$ at Ogwurube River (RS 1) and Ngene Ava River (RS 2) which is very high above the standard stipulated by WHO (2011) and is due to dissolved ferrous ion $\left(\mathrm{Fe}^{2+}\right)$ in the water. Hem (1985) states that high concentration of dissolved ferrous iron can occur in solution at sites of either reduction of ferric oxyhydroxides or oxidation of ferrous sulphides. Furthermore, boron fluctuates between minimum of $0.001 \mu \mathrm{g} / \mathrm{L}$ at $\mathrm{Ngbo}$ Hand Dug Well (HDW 1) to the maximum value of $0.011 \mu \mathrm{g} / \mathrm{L}$ at Ngbo Borehole (BH 1) with average value of $0.01 \mu \mathrm{g} / \mathrm{L}$.

\section{Hydrochemical facies}

\section{Piper diagram}

Piper's trilinear diagram (Piper 1944) was prepared to evaluate the geochemical sources and the connectivity between the underlying lithology and water chemistry of the study area. The interpretation of piper's trilinear diagram for surface and groundwaters in the study area revealed that $\mathrm{Ca}^{2+}$, 


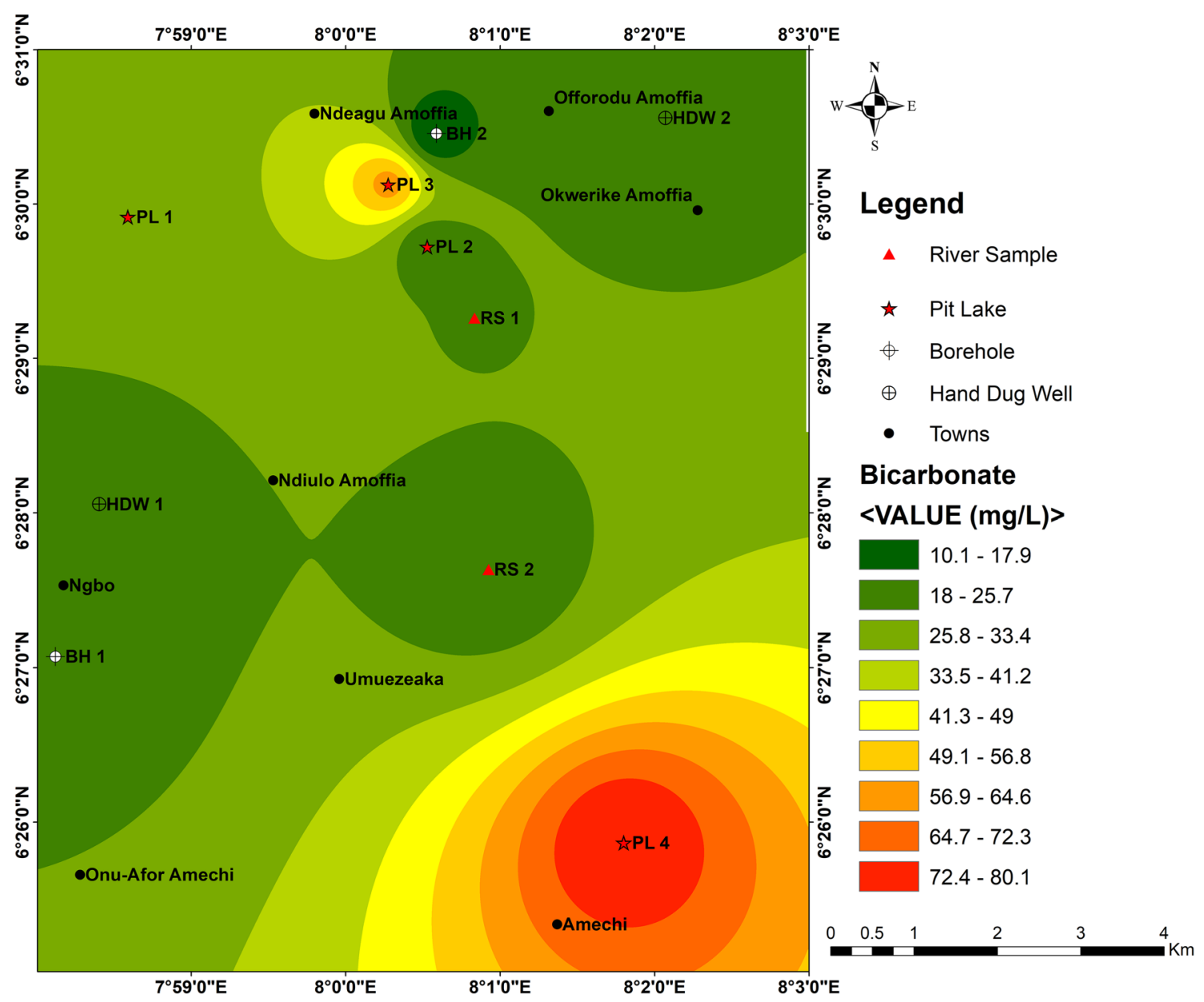

Fig. 10 Spatial distributions of bicarbonate in the study area

$\mathrm{Mg}^{2+}, \mathrm{CO}_{3}{ }^{-}$and $\mathrm{HCO}_{3}{ }^{-}$are the predominant cations and anions, therefore, suggesting equal dominance of strong alkaline earth metals; hence, the water samples are classified as $\mathrm{Ca}^{2+}-\mathrm{CO}_{3}{ }^{-}$and $\mathrm{Mg}^{2+}-\mathrm{HCO}_{3}{ }^{-}$hydrochemical facies (Fig. 11).

\section{Stiff diagram}

Stiff (1951) plot was used to classify the water qualities of the study area based on their similarity in shape. Waters of uniform quality have a similar shape. The diagram plots cations on the left and anions to the right-hand side. This classification method is a complement to Piper Trilinear diagram. Water sample from PL 1, BH 1, PL 2, PL 3, PL 4, RS 1, HDW 1 and HDW 2 displays peculiar shapes, with $\mathrm{Ca}^{2+}$ being the dominant cations, while $\mathrm{HCO}_{3}{ }^{-}+\mathrm{CO}_{3}{ }^{-}$is the dominant anion while BH 2 and RS 2 reveal similar shapes, with $\mathrm{Mg}^{2+}$ being the dominant cation, whereas $\mathrm{HCO}_{3}{ }^{-}+\mathrm{CO}_{3}{ }^{-}$is the dominant anion. The distribution of the various hydrochemical facies can be clearly seen in Fig. 12a, b.

\section{Durov diagram}

The major cations and anions of the water samples were plotted on Durov's diagram since it helps in the characterization of evolutionary trends and reveals the hydrochemical processes occurring in any surface and groundwater system. The Durov plot revealed two geochemical processes that could control the water chemistry of the area. Most of the surface and groundwater samples revealed $\mathrm{Ca}^{2+}$ and $\mathrm{CO}_{3}{ }^{2-}+\mathrm{HCO}_{3}{ }^{-}$dominant. These usually result from ionic exchange of $\mathrm{Ca}^{2+}$ and $\mathrm{CO}_{3}{ }^{2-}+\mathrm{HCO}_{3}{ }^{-}$rich waters or as a result of the water exhibiting simple dissolution, mixing or dissolution influences. However, other samples showed $\mathrm{Na}^{+}+\mathrm{K}^{+}$and partly $\mathrm{Cl}^{-}$exhibiting probably mixing or uncommon dissolution (Fig. 13). 
Fig. 11 Piper trilinear diagram

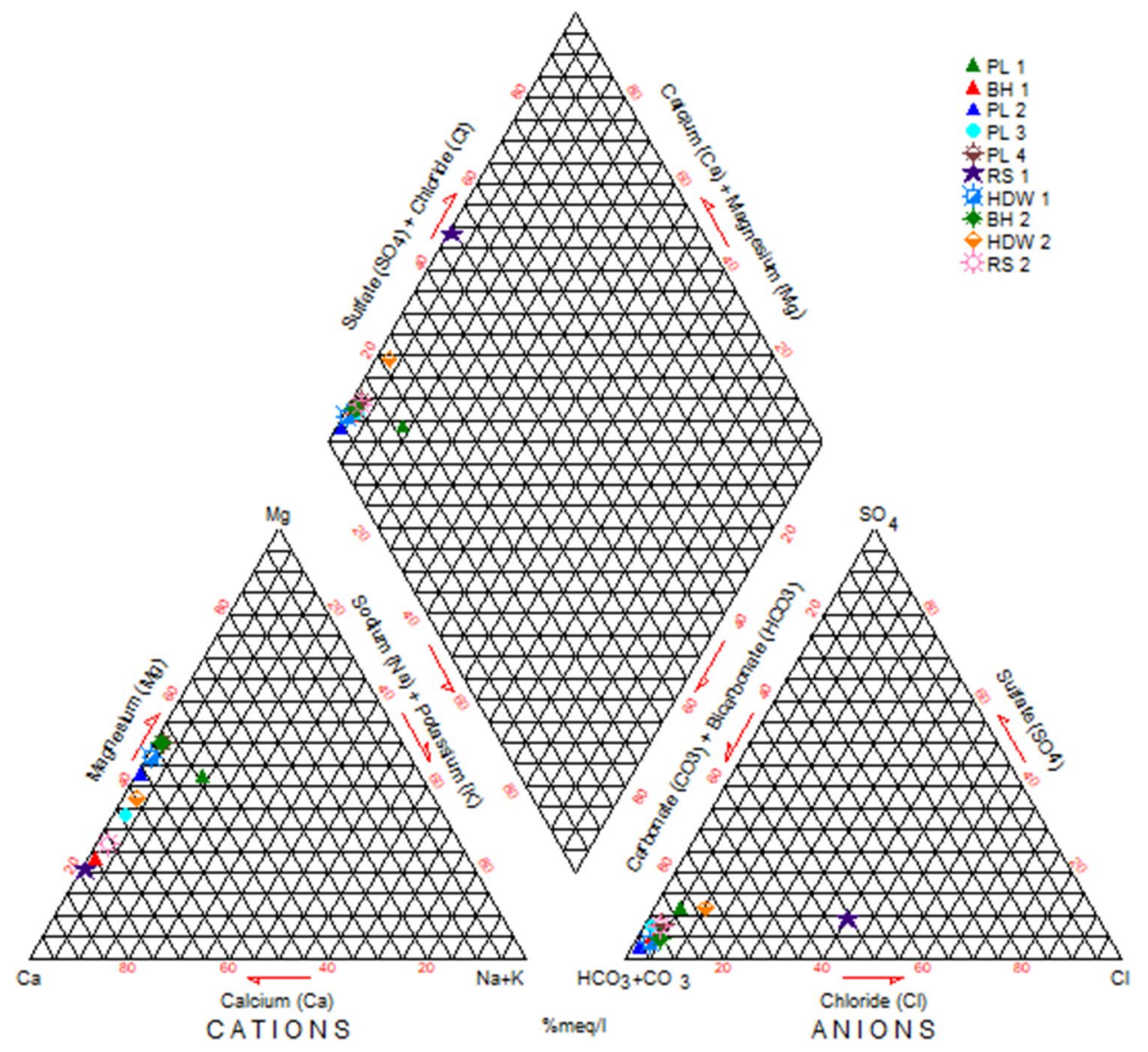

\section{Geochemical process}

The results of ionic ratios were used to infer the geochemical processes and factors responsible for the modification of surface and groundwater chemistry of the study area. The identified processes are interpreted in detail in the following sections. The relationships among the $\mathrm{Na} / \mathrm{Cl}, \mathrm{Na} / \mathrm{HCO}_{3}{ }^{-}$, $\mathrm{HCO}_{3}{ }^{-} / \mathrm{Ca}^{2+}+\mathrm{Mg}^{2+}$, total cations $/ \mathrm{Ca}^{2+}+\mathrm{Mg}^{2+}, \mathrm{Na}^{+}+\mathrm{K}^{+} /$ $\mathrm{Cl}^{-}+\mathrm{SO}_{4}{ }^{2-}$ and total cations $/ \mathrm{Na}^{+}+\mathrm{K}^{+}$can be used to deduce the evolution of ions and the processes prevailing in water composition (Table 4). Forward and reverse ion exchange processes often influence the origin of geochemistry of surface and groundwater systems. However, forward ion exchange process is described by the replacement of the $\mathrm{Na}^{+}$ion on clay minerals by $\mathrm{Ca}^{2+}$ and $\mathrm{Mg}^{2+}$ ions in surface and groundwater systems and $\mathrm{Mg}$ (Barzegar et al. 2018). In a similar manner, reverse ion exchange process is interpreted by the displacement of $\mathrm{Ca}$ and $\mathrm{Mg}$ ions on clay minerals by $\mathrm{Na}$ ion in the surface and groundwater systems (Barzegar et al. 2018). The hydrochemical data of the analysed samples are showcased on $\mathrm{Na}^{+}$vs. $\mathrm{Cl}^{-}$scatter plot. However, a scattered plot of sodium against chloride as shown in Fig. 14a revealed that most of the samples are plotting above $1: 1$ equiline, suggesting reverse ion exchange which is chiefly controlled by water-rock interaction, most likely derived from the weathering of silicate minerals, while few samples are plotting below 1:1 equiline, indicating forward ion exchange. At the same time, the scattered diagram of $\mathrm{Na}^{+}$ vs $\mathrm{HCO}_{3}{ }^{-}$highlighted that all the samples lie above $1: 1$ equiline, suggesting the presence of calcite weathering. Only one sample lie below the 1:1 equiline showing that silicate weathering occurs (Fig. 14b). The evidence of calcite weathering can be explained by the relationship among $\mathrm{Ca}+\mathrm{Mg}$ versus $\mathrm{HCO}_{3}$ (Fig. 14c). Moreover, the evaporation process would cause high concentration of all mineral species in water (Maya and Loucks (1995). The scattered plot of $\mathrm{Ca}+\mathrm{Mg}$ vs. total cations reveals that all the data fall on the above the 1:1 equiline, suggesting that $\mathrm{Na}$ and $\mathrm{K}$ is not the main source for the increase of TDS (Fig. 14d). Meanwhile, a scatter plot is shown in Fig. 14e illustrating that the majority of the samples lie above the 1:1 equiline suggesting that ions result from silicate weathering (reverse ion exchange), the dominant of $\mathrm{Cl}+\mathrm{SO}_{4}{ }^{2-}$ over $\mathrm{Na}+\mathrm{K}$ indicates silicate weathering and also that the higher concentration of alkalis is from precipitation as reported by Garrels and Mackenzie (1971). The Na+K vs. total cations scatter plot (Fig. 14f) of the study area shows that most of the sample points fall on the total cations trend. This suggests that the cations in the surface and groundwater might have been derived from silicate weathering. 
Fig. 12 a, b Stiff diagram showing water type in the study area

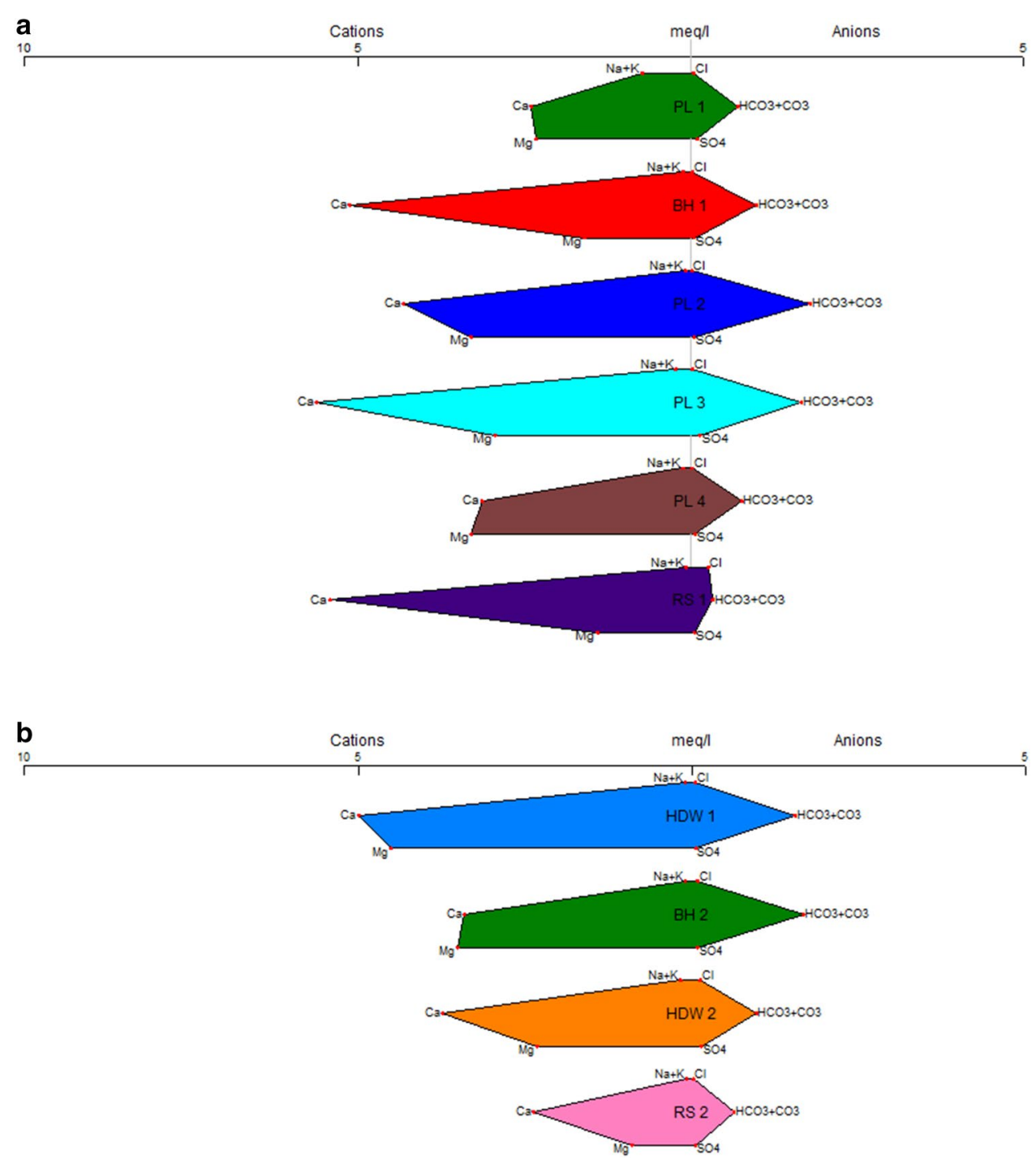

\section{Statistical analysis}

\section{Correlation matrix}

From the Pearson correlation matrix, the values of (r) can be classified into positive high and low as well as negative high and low correlations. At high positive correlation, values were observed for the parameters of $\mathrm{CO}_{3}{ }^{2-}-\mathrm{Mg}^{2+}$ (0.73), $\mathrm{SO}_{4}{ }^{2-}-\mathrm{Na}^{+}(0.45), \mathrm{SO}_{4}{ }^{2-}-\mathrm{pH}(0.39), \mathrm{HCO}_{3}{ }^{-}-\mathrm{pH}$ (0.37), $\mathrm{HCO}_{3}{ }^{-}-\mathrm{SO}_{4}{ }^{2-}$ (0.37) and $\mathrm{HCO}_{3}{ }^{-}$-Temp. (0.31), indicating the strong relation between these variables. A low positive correlation value was observed for the parameters of $\mathrm{CO}_{3}{ }^{2-}-\mathrm{K}^{+}(0.29), \mathrm{K}^{+}-\mathrm{Mg}^{2+}(0.29)$, $\mathrm{HCO}_{3}{ }^{-}-\mathrm{Ca}^{2+}$ (0.28), TDS-Temp. (0.28), $\mathrm{K}^{+}-\mathrm{Temp} .(0.23)$, $\mathrm{CO}_{3}{ }^{2-}-\mathrm{EC}(0.22), \mathrm{HCO}_{3}{ }^{-}-\mathrm{Mg}^{2+}$ (0.22), $\mathrm{Ca}^{2+}-\mathrm{Temp}$. (0.21), $\mathrm{Cl}^{-}-\mathrm{EC}(0.19), \mathrm{Na}^{+}-\mathrm{pH}(0.17), \mathrm{Mg}^{2+}-\mathrm{EC}(0.17)$, $\mathrm{Mg}^{2+}-\mathrm{Ca}^{2+}(0.16), \mathrm{CO}_{3}{ }^{2-}-\mathrm{Ca}^{2+}(0.15), \mathrm{HCO}_{3}{ }^{-}-\mathrm{Na}^{+}(0.14)$,
$\mathrm{EC}-\mathrm{pH}$ (0.13), $\mathrm{CO}_{3}{ }^{2-}-\mathrm{pH}(0.12), \mathrm{SO}_{4}{ }^{2-}-\mathrm{Mg}^{2+}(0.10)$, $\mathrm{Na}^{+}-\mathrm{TDS}(0.07), \mathrm{SO}_{4}{ }^{2-}-\mathrm{EC}(0.05), \mathrm{SO}_{4}{ }^{2-}-\mathrm{Cl}^{-}(0.03)$, $\mathrm{Cl}^{-}-$Temp. (0.03), $\mathrm{SO}_{4}{ }^{2-}-\mathrm{Ca}^{2+}(0.02)$ and Temp.-pH (0.02). The second type of correlation values which is highly negative correlation observed for the parameters $\mathrm{SO}_{4}{ }^{2-}-\mathrm{K}^{+}(-0.78), \mathrm{CO}_{3}{ }^{2-}-\mathrm{Temp} .(-0.56), \mathrm{Na}^{+}-\mathrm{EC}$ $(-0.56), \mathrm{SO}_{4}{ }^{2-}-\mathrm{TDS}(-0.54), \mathrm{SO}_{4}{ }^{2-}-\mathrm{Temp} .(-0.47)$, $\mathrm{HCO}_{3}{ }^{-}-\mathrm{Cl}^{-}(-0.46), \mathrm{Mg}^{2+}-\mathrm{TDS}(-0.45), \mathrm{HCO}_{3}{ }^{-}-\mathrm{K}^{+}$ $(-0.44) \mathrm{Na}^{+}-\mathrm{Ca}^{2+}(-0.39), \mathrm{Cl}^{-}-\mathrm{pH}(-0.38), \mathrm{CO}_{3}{ }^{2-}-\mathrm{Na}^{+}$ $(-0.36), \mathrm{Ca}^{2+}-\mathrm{TDS}(-0.36), \mathrm{K}^{+}-\mathrm{Na}^{+}(-0.34), \mathrm{TDS}-\mathrm{EC}$ $(-0.34)$ and TDS $-\mathrm{pH}(-0.32)$, which indicates the strong relation between these variables, and also the low negative correlation for $\mathrm{Cl}^{-}-\mathrm{Mg}^{2+}(-0.29), \mathrm{Cl}^{-}-\mathrm{K}^{+}(-0.29)$, EC-Temp. (- 0.23), $\mathrm{Ca}^{2+}-\mathrm{EC}(-0.22), \mathrm{HCO}_{3}{ }^{-}-\mathrm{EC}$ (- 0.21), $\mathrm{Mg}^{2+}-\mathrm{Temp} .(-0.19), \mathrm{CO}_{3}{ }^{2-}-\mathrm{Cl}^{-}(-0.17)$, $\mathrm{CO}_{3}{ }^{2-}-\mathrm{TDS}(-0.16), \mathrm{K}^{+}-\mathrm{Ca}^{2+}(-0.15), \mathrm{Na}^{+}-\mathrm{Cl}^{-}(-0.14)$, $\mathrm{HCO}_{3}{ }^{-}-\mathrm{CO}_{3}{ }^{-}(-0.14) \mathrm{CO}_{3}{ }^{2-}-\mathrm{SO}_{4}{ }^{2-}(-0.12), \mathrm{Ca}^{2+}-\mathrm{pH}$ 
Fig. 13 Durov diagram of the study area

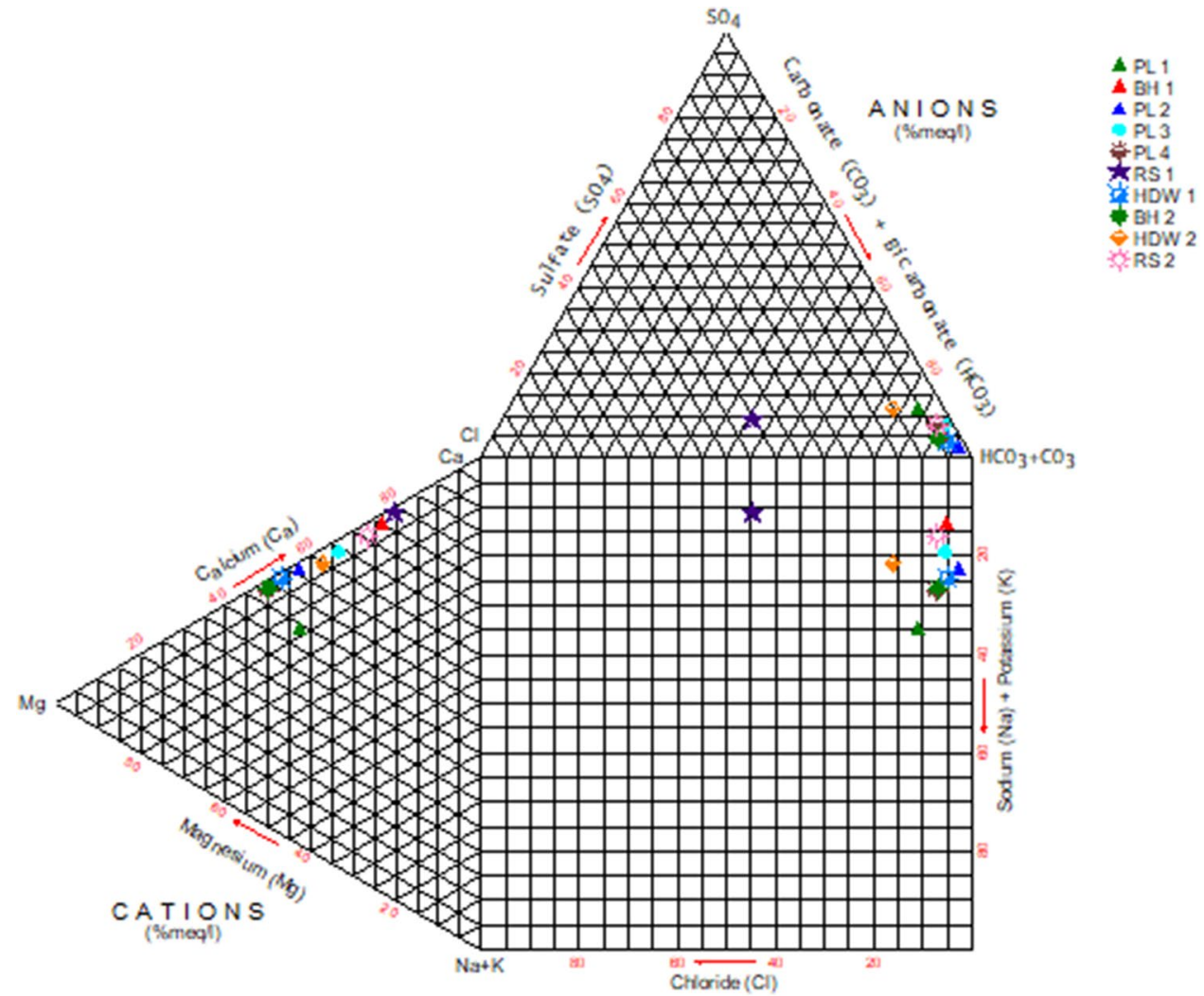

\begin{tabular}{llllllll}
\hline Parameters (meq/l) & $\mathrm{Na}^{+}$ & $\mathrm{Cl}^{-}$ & $\mathrm{HCO}_{3}^{-}$ & $\mathrm{Ca}+\mathrm{Mg}$ & Total cation & $\mathrm{Na}+\mathrm{K}$ & $\mathrm{Cl}+\mathrm{SO}_{4}$ \\
\hline PL 1 & 0.69 & 0.04 & 0.49 & 4.71 & 5.43 & 0.72 & 0.14 \\
BH 1 & 0.07 & 0.03 & 0.33 & 6.71 & 6.82 & 0.11 & 0.08 \\
PL 2 & 0.04 & 0.02 & 0.99 & 7.60 & 7.67 & 0.07 & 0.07 \\
PL 3 & 0.21 & 0.03 & 1.31 & 8.56 & 8.78 & 0.22 & 0.17 \\
PL 4 & 0.06 & 0.03 & 0.33 & 6.42 & 6.53 & 0.11 & 0.10 \\
RS 1 & 0.04 & 0.27 & 0.17 & 6.80 & 6.87 & 0.07 & 0.33 \\
HDW1 & 0.05 & 0.05 & 0.33 & 9.50 & 9.60 & 0.10 & 0.11 \\
BH 2 & 0.07 & 0.03 & 0.33 & 6.92 & 7.02 & 0.10 & 0.18 \\
HDW2 & 0.17 & 0.009 & 0.30 & 6.06 & 6.24 & 0.18 & 0.27 \\
RS 2 & 0.04 & 0.04 & 0.41 & 2.46 & 2.54 & 0.06 & 0.07 \\
\hline
\end{tabular}

$(-0.12), \mathrm{HCO}_{3}{ }^{-}-\mathrm{CO}_{3}{ }^{2-}(-0.11), \mathrm{Na}^{+}-\mathrm{Temp} .(-0.08)$, $\mathrm{Na}^{+}-\mathrm{Mg}^{2+}(-0.08)$ and $\mathrm{Cl}^{-}-\mathrm{TDS}(-0.04)$ were obtained (Table 5).

\section{Principal component analysis}

The result obtained from the component analyses reveals five components of physico-chemical parameters (Table 6). The first component accounts for $25.67 \%$ total variance of eigen value. These parameters may have been enriched by same sources, most likely from weathering and leaching of minerals from underlying lithology of the study area. The second component accounts for approximately $28.18 \%$ of the total variance. These parameters may have been enriched in both surface and groundwater of the study area by activities related to mine tailings dumped along water ways. The third component accounts for about $30.58 \%$ of the total variance. These parameters may have been enriched in the surface and groundwater systems of the area by the activities relating to leachate from mining activities.

The 2D and 3D plots of principal component analyses (PCA) as revealed in Figs. 15, 16. The 2D component 

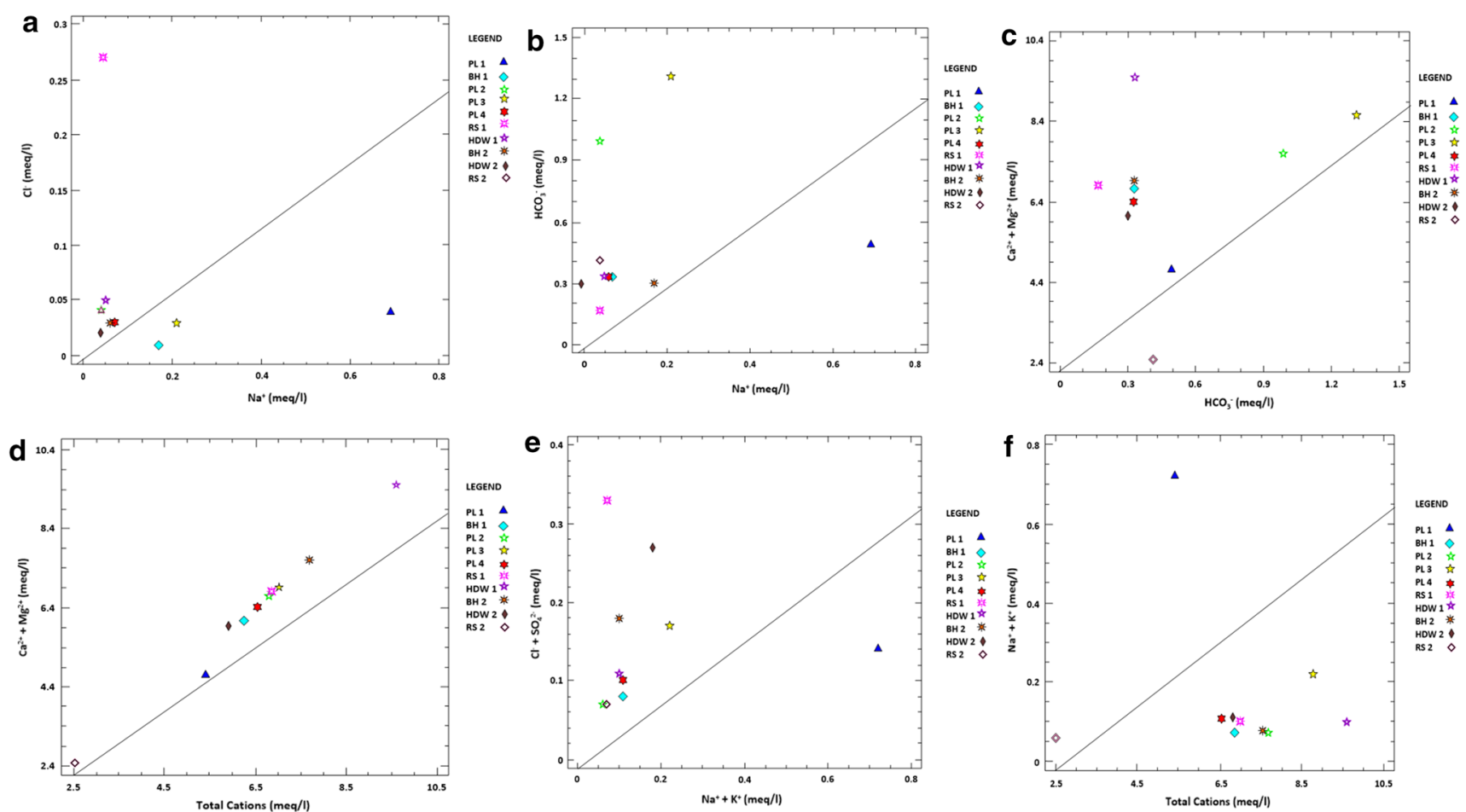

Fig. 14 Scattered plot of various ionic ratios of the study area

Table 5 Pearson correlation matrix of the physico-chemical parameters

\begin{tabular}{|c|c|c|c|c|c|c|c|c|c|c|c|c|}
\hline & $\mathrm{pH}$ & Temp. & EC & TDS & $\mathrm{Ca}^{2+}$ & $\mathrm{Mg}^{2+}$ & $\mathrm{Na}^{+}$ & $\mathrm{K}^{+}$ & $\mathrm{Cl}^{-}$ & $\mathrm{SO}_{4}^{2-}$ & $\mathrm{CO}_{3}^{2-}$ & $\mathrm{HCO}_{3}{ }^{-}$ \\
\hline $\mathrm{pH}$ & 1.00 & & & & & & & & & & & \\
\hline Temp. & 0.02 & 1.00 & & & & & & & & & & \\
\hline $\mathrm{EC}$ & 0.13 & -0.23 & 1.00 & & & & & & & & & \\
\hline TDS & -0.32 & 0.28 & -0.34 & 1.00 & & & & & & & & \\
\hline $\mathrm{Ca}^{2+}$ & -0.12 & 0.21 & -0.22 & -0.36 & 1.00 & & & & & & & \\
\hline $\mathrm{Mg}^{2+}$ & 0.62 & -0.19 & 0.17 & -0.45 & 0.16 & 1.00 & & & & & & \\
\hline $\mathrm{Na}^{+}$ & 0.17 & -0.08 & -0.56 & 0.07 & -0.39 & -0.08 & 1.00 & & & & & \\
\hline $\mathrm{K}^{+}$ & 0.03 & 0.23 & 0.07 & 0.11 & -0.15 & 0.29 & -0.34 & 1.00 & & & & \\
\hline $\mathrm{Cl}^{-}$ & -0.38 & 0.03 & 0.19 & -0.04 & 0.32 & -0.29 & -0.14 & -0.29 & 1.00 & & & \\
\hline $\mathrm{SO}_{4}{ }^{2-}$ & 0.39 & -0.47 & 0.05 & -0.54 & 0.02 & 0.10 & 0.45 & -0.78 & 0.03 & 1.00 & & \\
\hline $\mathrm{CO}_{3}{ }^{2-}$ & 0.12 & -0.56 & 0.22 & -0.16 & 0.15 & 0.73 & -0.36 & 0.29 & -0.17 & -0.12 & 1.00 & \\
\hline $\mathrm{HCO}_{3}{ }^{-}$ & 0.37 & 0.31 & -0.21 & -0.14 & 0.28 & 0.22 & 0.14 & -0.44 & -0.46 & 0.37 & -0.11 & 1.00 \\
\hline
\end{tabular}

loading, $\mathrm{pH}, \mathrm{Mg}^{2+}, \mathrm{CO}_{3}{ }^{2-}, \mathrm{EC}$ and $\mathrm{Ca}^{2+}$ load close to one another exhibiting same source of enrichment. Consequently, $\mathrm{Na}^{+}, \mathrm{SO}_{4}{ }^{2-}$ and $\mathrm{HCO}_{3}{ }^{-}$load close to each other also suggests the same source of enrichment. Similarly, $\mathrm{Cl}^{-}$, Temp. and TDS load close to each other, also suggesting same source enrichment. $\mathrm{K}^{+}$appears on its own, suggesting different sources of enrichment. Also, for the 3D component plot, it is also observed that the elements plot on three sides.

\section{Conclusion}

This research demonstrated the geochemical evaluation of carbonate aquifers in Ngbo and environs via different approaches. The water quality with respect to domestic and drinking purposes was assessed. Ten water samples were collected from pit lakes, hand dug wells, boreholes and rivers, analysed and assessed for domestic and drinking water 
Table 6 Principal components of ten water quality variables

\begin{tabular}{llllll}
\hline & Component & Component & Component & Component & Component \\
\hline Row & 1 & 2 & 3 & 4 & 5 \\
1 & 0.372 & -2.604 & 1.387 & -1.826 & 0.679 \\
2 & 1.758 & 0.179 & 0.397 & 0.387 & 1.856 \\
3 & 0.152 & 0.292 & 2.108 & 1.039 & -0.032 \\
4 & -2.466 & -2.238 & -0.032 & 1.952 & -0.236 \\
5 & -0.359 & 1.299 & 1.070 & -0.354 & -1.688 \\
6 & 2.558 & -0.349 & -2.097 & 1.643 & -0.285 \\
7 & -1.462 & 2.603 & 0.393 & 0.538 & 0.546 \\
8 & -0.890 & 1.598 & -1.287 & -1.271 & 0.906 \\
9 & -1.702 & -0.875 & -2.009 & -1.143 & -0.319 \\
10 & 2.038 & 0.095 & 0.071 & -0.965 & -1.426 \\
Eigenvalue & 5.62 & 4.21 & 2.44 & 2.50 & 2.08 \\
$\%$ of variance explained & 30.23 & 20.08 & 19.41 & 17.73 & 12.55 \\
$\%$ cumulative variance & 25.67 & 28.18 & 30.58 & 34.23 & 56.11 \\
\hline
\end{tabular}

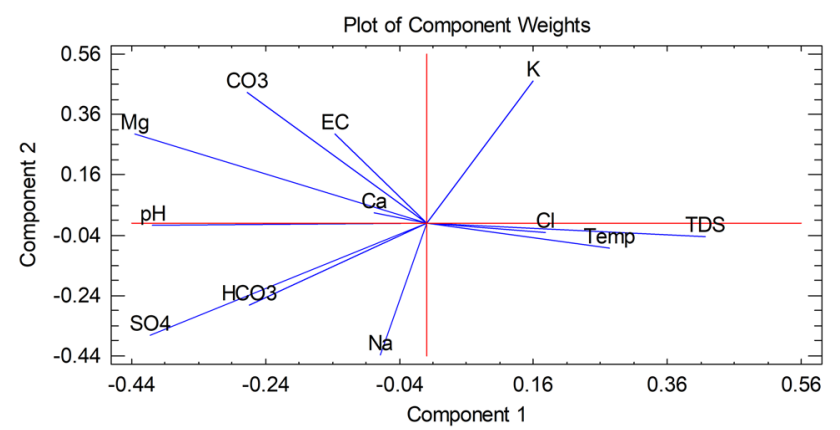

Fig. 15 2D component loading of the area

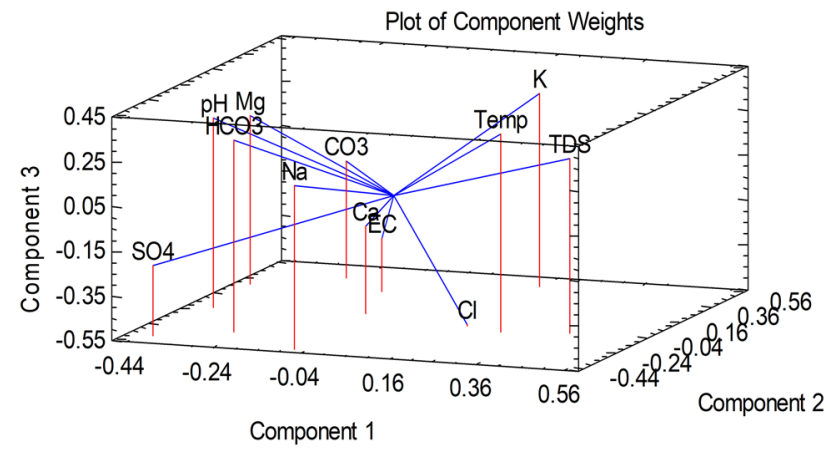

Fig. $163 \mathrm{D}$ component loading of the area

quality. The $\mathrm{pH}$ value of the water was slightly acidic to alkaline in nature. Based on TDS classification, the entire water samples are non-saline in nature. The analysis results show that the mean concentration of cations and anions followed the order: $\mathrm{Ca}^{2+}>\mathrm{Mg}^{2+}>\mathrm{Na}^{+}>\mathrm{K}^{+}>\mathrm{Fe}^{2+}$ and $\mathrm{HCO}_{3}{ }^{-}>\mathrm{CO}_{3}{ }^{2-}>\mathrm{SO}_{4}{ }^{2-}>\mathrm{Cl}^{-}$, respectively. Based on the NDWQS (2007) and WHO (2011) standard limits, about
$90 \%$ of the water samples are suitable for domestic and drinking purposes. The greater hydrochemical facies was a $\mathrm{CaCO}_{3}{ }^{2-}+\mathrm{HCO}_{3}$ type observed using the Piper trilinear, Stiff and Durov plots. The analysis results revealed that the carbonate weathering due to calcite dissolution was the major geochemical process contributing to the cations and anions of the aquifer water.

Geochemical parameters such as $\mathrm{Cl}^{-}, \mathrm{Na}^{+}$and $\mathrm{K}^{+}$show good interrelationship with positive factor loadings among the ions.

Acknowledgement The authors would like to appreciate the effort of Dr. S.I Umeh, a senior technologist of the Department of Crop Science, University of Nigeria, Nsukka who helped in some of the laboratory analysis of the samples.

Open Access This article is distributed under the terms of the Creative Commons Attribution 4.0 International License (http://creativeco mmons.org/licenses/by/4.0/), which permits unrestricted use, distribution, and reproduction in any medium, provided you give appropriate credit to the original author(s) and the source, provide a link to the Creative Commons license, and indicate if changes were made.

\section{References}

Agagu OK, Fayose EA, Peter SW (1985) Stratigraphy and sedimentation in the Senomanian Anambra Basin of Eastern Nigeria. Nig J Min Geol 22:25-36

Barzegar R, Moghaddam AA, Adamowski J, Nazemi AH (2018) Assessing the potential origins and human health risks of trace elements in groundwater: a case study in the Khoy plain, Iran. Environ Geochem Health. https://doi.org/10.1007/s1065 3-018-0194-9

Castanier S, Le Matayer-Levrel G, Perthuisot JP (1999) Carbonate precipitation and limestone genesis-the microbiological point of view. Geol 126(1-4):9-23 
Field MS (1988) The vulnerability of karst aquifers to contamination. Hydro Sci Tech 4:130-142

Garrels RM, Mackenzie FT (1971) Evolution of sedimentary rocks. WW Norton, New York

Ghandour EIM, Khalil JB, Atta SA (1985) Distribution of carbonates, bicarbonates and $\mathrm{pH}$ values in groundwater of the Nile delta region, Egypt. Groundwater 23:35-41

Hanshaw BB, Back W (1979) Major geochemical processes in the evolution of carbonate-aquifer system. J Hydrol 43:287-313

Hem JD (1985) Study and interpretation of the chemical characteristics of natural water ( $3 \mathrm{rd}$ ed)

Hughes TH, Memon BA, LaMoreaux PE (1994) Landfills in karst terrains. Bull Assoc Eng Geol 31:203-208

Igbozuluike MU (1975) Vegetation types. In: Ofomata G (ed) Nigeria map of eastern states. Ethiopa publishers Ltd, Benin, pp 30-32

Igwe O, Ifediegwu SI, Ozoko DC (2018) Quality of natural waters in carbonate aquifers at a densely populated Odukpani area of cross river state, Southern Nigeria. Cogent Geosci 4:1-17

Jalali M (2005) Major ion chemistry of ground waters in the Bahar area, Hamadan, Western Iran. J Env Geol 47:763-777

Kile DE, Eberl DD, Hoch AR, Reddy MM (2000) An assessment of calcite crystal growth mechanisms based on crystal size distributions. Geochem Cosmochem Acta 64(17):2937-2950

Maya AL, Loucks MD (1995) Solute and isotopic geochemistry and groundwater flow in the Central Wasatch Range, Utah. J Hydrol 172:31-59

Moral F, Cruz-Sanjulian JJ, Olias M (2008) Geochemical evolution of groundwater in the carbonate aquifers of Sierra de Segura, Betic Cordillera, Southern Spain. J Hydrol 360:281-296

Murat RC (1972) Stratigraphy and palaeogeography of the Cretaceous and Lower Tertiary in Southern Nigeria. In: Dessauvagie FJ, Whiteman AJ (eds) African Geology. University of Ibadan Press, Ibadan, pp 251-266

NSDWQ (2007) Nigerian standard for drinking water quality, Nigeria Industrial Standard. NIS 554, Standard Organization of Nigeria, Lagos, p 30

Nwajide CS (1990) Cretaceous sedimentation and paleogeography of Central Benue Trough. In: Ofoegbu, C. O. Ed. The Benue Trough, Structure and Evolution. International Mongraph Series, Braunschweig, pp 19-38

Nwajide CS (2013) Geology of Nigeria's Sedimentary Basins. CSS Bookshops Ltd, Lagos, p 565

Ojoh KA (1992) The southern part of the Benue Trough (Nigeria) Cretaceous stratigraphy, basin analysis, paleooceanography and geodynamic evolution in the Equatorial domain of the South Atlantic. Nig Associa Petrol Explora Bull 7(2):131-152

Ozoko DC (2015) Origin of dissolved solids in cretaceous aquifers at Ngbo, Ebonyi State, Nigeria: a preliminary assessment. Int $\mathbf{J}$ Innov Sci Eng Tech 2:247-253
Panthi SR (2003) Carbonate chemistry and calcium carbonate saturation state of rural water supply projects in Nepal. In: Seventh International Water Technology Conference Egypt. 1-3:545-560

Petters SW (1991) Regional Geology of Africa. Springer Verlag, Berlin, $\mathrm{p} 722$

Petters SW, Ekweozor CM (1982) Petroleum geology of Benue Trough and southeastern Chad Basin, Nigeria. Am Assoc Petrol Geol Bull 66:1141-1149

Piper AM (1944) A graphical procedure in the geochemical interpretation of water analysis. Am Geophys Union Trans 25:914-923

Plummer LN, Busby JF, Lee RW, Hanshaw BB (1990) Geochemical modelling of the Madison Aquifer in parts of Montana, Wyoming and South Dakota. Wat Res Res 26(9):1981-2014

Reyment RA (1965) Aspects of the Geology of Nigeria. The stratigraphy of the Cretaceous and Cenozoic Deposits. Ibadan University Press, Ibadan, p 145

Robinove CJ, Langford RH, Brookhart JW (1958) Saline water resource of North Dakota. In US Geological Survey Water Supply, Paper No. 1428, p 72

Romanov D, Gabrovsek F, Dreybrodt W (2003) The impact of hydrochemical boundary conditions on the evolution of limestone karst aquifers. J Hydrol 276:240-253

Stiff HA (1951) The interpretation of chemical water analysis by means of patterns. J Petrol Tech 3(10):15-17

Uma KO, Onuoha KM, Egboka BCE (1990) Hydrochemical facies, groundwater flow pattern and origin of saline waters in parts of the western flank of the Cross River basin, Nigeria. In: Ofoegbu $\mathrm{CO}$ (ed) The benue trough structure and evolution, friedr. Vieweg and Sohn, Braunschweig, pp 115-134

Umeji OP (1984) Ammonite paleoecology of the Ezeaku Formation, Southeastern, Nigeria. J Min Geol 21:55-59

Umeji OP (1993) Hummocky cross stratification in Turonian Ezeaku Sandstone of the Southeastern, Nigeria Sedimentological significance. J Min Geol 29(2):71-76

Umeji AC (2000) Evolution of the Abakaliki and the Anambra sedimentary basins, southeastern Nigeria. To SPDC Ltd, Project Rpt, p 155

U.S. Geological Survey Water-Supply Paper 2254, Washington DC, p 263

White WB, Culver DC, Herman JS, Kane TC, Mylroie JE (1995) Karst lands. Am Sci 83:450-459

World Health Organization WHO (2011) Guidelines for drinking water quality criteria, 4th ed. Geneva, pp 307-441

Publisher's Note Springer Nature remains neutral with regard to jurisdictional claims in published maps and institutional affiliations. 